\title{
O DESASTRE VIVENCIADO: A IMPORTÂNCIA DA MEMÓRIA SOCIAL DE IDOSOS ATRAVÉS DA ANÁLISE DO CASO DE SÃO LUIZ DO PARAITINGA
}

\section{EXPERIENCED DISASTER: THE IMPORTANCE OF SOCIAL MEMORY OF THE ELDERLY THROUGH THE CASE OF SÃO LUIZ DO PARAITINGA}

\author{
Juliana Sartori* \\ Norma Valencio**
}

\section{Introdução}

Tão importante quanto os atributos geográficos e físicos que dão feições ambientais prévias a um lugar, o qual será produzido de modo singular pela coletividade local, tem sido o seu par indissociável, a saber, a memória social. 0 sujeito que privilegiadamente a aninha, na vida comunitária, é o idoso.

Se considerarmos o lugar como o dinamismo indissociável entre o território e a animação coletiva do saber-fazer local, relação na qual o corpo e o ambiente se fundem (CLAVAL, 2006), podemos dizer que a memória social é o seu espírito, isto é, aquilo que enreda simbolicamente a coletividade numa trajetória compartilhada.
Nessa perspectiva, a memória social local pode ser compreendida como o fio condutor do tempo social que vincula um dado grupo social em seu lugar, atuando como um contínuo processo de amalgamação de conhecimentos e experiências localizados da vida de sua gente.

Os significados atribuídos a certos acontecimentos marcantes do lugar, bem como os concernentes àquilo que ocorre na sociabilidade da vida cotidiana de um lugar, não são perenes. Há uma constante necessidade, individual e coletiva, de revisitação do passado à luz de novos acontecimentos do presente, buscando-se uma ancoragem de significados para as práticas mais imediatas adotadas, sejam elas sistemáticas ou

\footnotetext{
* Socióloga, Mestre em Ciências pelo Programa de Pós-Graduação em Ciências da Engenharia Ambiental da Universidade de São Paulo - USP (São Paulo/SP/Brasil). sartoriju@gmail.com.

** Professora do Programa de Pós-Graduação em Ciências da Engenharia Ambiental (PPGSEA) da USP (São Paulo/SP/Brasil) e do Programa de Pós-Graduação em Ciências Ambientais (PPGCam) da UFSCAR (São Carlos/SP/Brasil). normaf@terra.com.br.
} 
não usuais. E assim, também, são modeladas e remodeladas a todo momento as perspectivas para o futuro.

Severas adversidades que porventura se imponham, simultaneamente, tanto à vida privada quanto à vida pública de um lugar, agem como duras provações à memória social, isto é, testam os limites dos significados previamente atribuídos às relações e às coisas. Por um lado, alguns desses limites mostram-se resistentes, devido à sua forte sedimentação no habitus - que é adquirido mediante a interação social, e se constitui como classificador e organizador dessas interações (BOURDIEU, 2009). Enquanto isso, outros limites adquirem maior fluidez para aglutinar novas interpretações acerca das vivências do passado, das circunstâncias do presente e das incertezas quanto ao futuro. Tal fluidez suscita novas associações entre as ocorrências do mundo e a posição do sujeito no mundo.

Considerando o esforço de elaboração de uma tipologia de memória social elaborado por Sá (2007), através de uma consistente revisão e análise de literatura sobre o tema - dirigida para uma sedimentação da perspectiva psicossocial, mas, em grande medida, muito útil para outras ciências humanas e sociais -, poder-se-ia dizer, ao menos em caráter preliminar e nos termos da sociologia, que uma parte constitutiva de uma memória social sobre um dado desastre é a memória oficial e outra, a memória comum.

A primeira é produzida pelos documentos oficiais, que partem de variáveis padronizadas de formulários para captar as informações socioambientais locais desde uma perspectiva que se pretende externa e neutra aos fatos. A casa e o corpo se tornam números e, ainda, esses números são segmentados, inviabilizando nexos de sentido profundos sobre o lugar. Em seu pro- cesso de produção e de difusão, tais documentos referenciam as narrativas técnicas demandadas pelos meios de comunicação que fazem a cobertura do acontecimento e, assim, disseminam um tipo de interpretação que se tornará dominante sobre aquilo que se passou, e cujo caráter é essencialmente tecnocêntrico.

Já a memória comum é tecida por processos endógenos da comunidade residente afetada, processos esses que têm como fio condutor da narrativa a vivência desse acontecimento, a qual imbrica com frequência aspectos da esfera da vida privada com a vida pública local, uma vez que essas esferas são consideradas pelos narradores como mutuamente influenciáveis. Esses diferentes sujeitos e tipos de envolvimento acabam por definir focos muito diferentes para enquadrar o problema. Embora cada um deles, dentro de seu próprio subgrupo, possa apresentar singularidades interpretativas, aquilo que nesta oportunidade gostaríamos de ressaltar são as distinções de caráter mais abrangente na construção social dessas memórias, oficial e comum. Resultam, colocadas uma diante da outra, quase que num abismo interpretativo, cujas feições práticas se definem por distanciar os procedimentos técnicos adotados, em termos de resposta (resgate e reabilitação) ao desastre, daqueles procedimentos que os grupos sociais afetados adotam e/ou necessitariam que fossem tomados a fim de proteger a sua integridade em várias dimensões. Sá (2007) interpreta a memória comum como sendo elaborações afins de um grupo de pessoas que, eventualmente, sequer tenham interagido diretamente umas com as outras. Conforme Sá (2007, p. 293),

As memórias comuns podem ser vistas como coleções de muitas memórias pessoais acer- 
ca de um mesmo objeto, construídas independentemente umas das outras. Por força de sua participação comum em dado período histórico, em dada configuração cultural ou em dado estrato social, tais pessoas teriam sido expostas aos mesmos fatos, às mesmas informações, aos mesmos gostos, etc., e deles guardariam aproximadamente as mesmas lembranças.

Há um sujeito social, em particular, que detém especialmente o legado, dinâmico, da memória pessoal, capaz de se aglutinar numa memória comum e lograr tornar-se, processualmente, uma memória coletiva: trata-se do velho morador do lugar. É pela memória dos velhos moradores que as transformações ocorridas na vida cotidiana de um lugar, ao longo das gerações nele enraizadas, são capturadas em sua riqueza de detalhes e multidimensionalidade. Esse exercício reflexivo é realizado de uma forma que geralmente escapa da compreensão dos demais sujeitos que se circunscrevem mais ativamente tanto nas frações econômicas do processo histórico local quanto nas frações institucionais que elaboram a história oficial. A lembrança constitui a função social do velho, enfatiza Bosi (1979), e o ato de rememorar deste sujeito não é um simples desarmazenamento de impressões do passado, apoiado apenas na sua subjetividade, mas um esforço de reelaboração abastecido pelas situações coletivamente vividas no cotidiano e no presente. Isso é reiterado por Martins (2008, p. 129), ao mencionar que "Ao mesmo tempo em que apreendemos a memória através do imaginário, do sensocomum, construímos memórias através de nossas relações cotidianas que se perpetuam nos gestos, sentimentos e atitudes".

Dos variados acontecimentos trágicos que, eventualmente, envolvem um lugar e abatem-no, provocando considerável sofrimento social e exigindo dos seus velhos moradores um intenso esforço de reacomodação da memória social, destacam-se os desastres; o acalorado debate das ciências sociais sobre sua definição coloca inúmeras formas de compreensão em jogo. Uma defınição possível, como tentativa de síntese, é a de que o desastre é um tipo de crise, deflagrada por um acontecimento trágico e adstrita a um tempo social, na qual são desorganizadas, involuntária e severamente, as rotinas de uma dada comunidade, o que impõe danos e prejuízos, materiais e imateriais, particulares e coletivos, de grande monta (SOROKIN, 1949; QUARANTELLI, 1998; QUARANTELLI, 2005; PERRY, 2007; VALENCIO, 2012). Para que, numa dada localidade, os contornos e conteúdos sociais da singularidade dessa crise sejam preenchidos e ganhem a devida nitidez, em muito contribui a prática de rememoração dos seus velhos moradores. Eles podem produzir uma narrativa que vincula o visível ao invisível, bem como o particular ao coletivo da vida cotidiana local.

Tendo tais considerações em conta, este estudo aborda a importância da memória pessoal e comum de idosos acerca do desastre ocorrido, em janeiro do ano de 2010, no município de São Luiz do Paraitinga, localizado no interior do estado de São Paulo. Para tanto, são recuperados, preliminar e sucintamente, alguns dos aspectos considerados como os mais essenciais do debate das ciências sociais em torno dos temas dos desastres, dos idosos e da memória social para municiar a análise do caso em tela. Em seguida, são apresentados alguns números que subsidiam enxergar o panorama recente de ocorrências de desastres no Brasil, em meio ao qual inserimos uma breve problematização da forma de registro técnico 
do desastre ocorrido em São Luiz do $\mathrm{Pa}$ raitinga/SP, cujos documentos municiarão a construção de uma memória oficial. Tais sinteses, nas dimensões conceituais e contextuais de caráter mais geral, servem como pano de fundo para, numa abordagem sociológica, serem trazidas à tona as novas feições do desastre a partir das narrativas dos idosos.

Um desastre, sem dúvida, é um desses acontecimentos que os idosos, que estão severamente expostos aos diversos perigos que os rodeiam, retêm nas suas lembranças. No ato de rememorar o seu envolvimento específico, destacam-se em suas memórias pessoais os seus sentimentos e as suas sensações particulares (medo, insegurança, desamparo, angústia, urgências etc.). No entanto, como um desastre se define como uma tragédia de amplo espectro socioespacial, há múltiplos pontos de contato entre as memórias pessoais. Eventualmente, na medida em que sejam compartilhadas e transmitidas ao longo do tempo, essas memórias comuns são passíveis de se transformar em memórias coletivas, mais ricas em detalhes que a memória oficial. As narrativas de idosos permitem identificar que os sujeitos que as produzem não se referem a um mero evento territorial grave, separado da vida social local, mas a um acontecimento social espacialmente localizado que interrompe abruptamente as rotinas da vida cotidiana e as redefine em termos tanto materiais quanto simbólicos; portanto, em seu conjunto, as memórias pessoais dos idosos podem ser caracterizadas como parte constitutiva de uma memória comum que reporta uma experiência existencial coletiva marcante, transcendendo em muito ao alcance da visão oficial.

\section{A importância da memória social na com- preensão de um desastre como experiência de perturbação severa da vida cotidiana}

Para o homem comum, a vida cotidiana é o mais importante locus de relações sociais. É na vida cotidiana que as possibilidades do homem comum logram êxito em seus intentos, bem como as manifestações concretas e simbólicas do mundo se deparam com os seus limites através, principalmente, das regras de tráfego da sociabilidade local. Na convivência, os membros de uma coletividade produzem e partilham um senso comum (MARTINS, 1998) que é constantemente posto à prova.

As partes orgânicas da vida cotidiana são compostas pela organização do trabalho e da vida privada, assim como pelas práticas de lazer e de repouso, mesclando repetição e espontaneidade (HELLER, 2008). Devido à riqueza do universo dinâmico microssocial, a história vivenciada pelo homem comum não deve ser desprezada nos estudos das ciências humanas e sociais; ao contrário, serve como referência para a compreensão de processos históricos mais abrangentes, pois permite complementar, em alguns casos, e contrapor, em outros, as versões que ganham maior peso nas dimensões macrossociais da vida. A vida cotidiana, assim, “está no centro do acontecer histórico e não fora dele [...] Os grandes fatos históricos partem da vida cotidiana e a ela retornam" (HELLER, 2008, p. 34).

Em parte, a memória social de um lugar é consolidada pelas rotinas da vida cotidiana de sua coletividade e, noutra parte, abastecida pelos eventos críticos que a impossibilitam. Um desastre é, sem dúvida, um desses eventos críticos, cuja memória social é homeopaticamente processada nas interações sociais locais ao longo do tem- 
po, não sem sofrer os influxos de uma visão extracomunitária acerca do ocorrido.

Um desastre não é algo trivial, mas uma circunstância na qual proliferam tensões sociais de toda ordem. Em meio a essas tensões, destacam-se as diversas manifestações de violência do Estado em relação aos grupos sociais considerados em situação de desvantagem, quais sejam, os que se encontram expostos a certos perigos e não têm como se proteger devidamente deles. Um dos aspectos dessa violência é a insuficiência de atendimento público aos que apresentam grave comprometimento em termos da garantia de seus direitos mínimos vitais. Outro aspecto é a imposição da visão oficial sobre os acontecimentos, inspirada numa racionalidade tecnocêntrica, e sobre a qual são pautados, unilateralmente, os procedimentos públicos de remediação de danos e perdas, de modo a cercear os recursos de voz daqueles que vivenciam dramaticamente a situação, deixando-os à margem do Estado (DAS, 1995; DAS; POOLE, 1998). Contudo, experiências de aviltamento sociopolítico como essas podem fazer com que os grupos silenciados busquem caminhos alternativos para elaborar, reter e expressar os significados dramáticos vividos na ocasião, embora tais significados sigam desconsiderados pelo ente público. Um desses caminhos é o da memória social local.

A memória em torno de um desastre vivenciado consiste em uma abordagem que permite compreender as ligações entre as dimensões materiais e as dimensões simbólicas do tecido microssocial comunitário imerso nesse acontecimento trágico, possibilitando um novo entendimento do sujeito no mundo, abordagem esta que a interpretação institucional recorrentemente descarta. Tais ligações são as que permitem revelar que, por detrás da crise aguda - frequentemente denominada como sendo "o dia do desastre" -, desenvolve-se uma crise crônica, na qual tanto as insuficiências quanto as omissões de providências públicas voltadas para os grupos sociais mais fragilizados resultam em debilitá-los ainda mais (VALENCIO, 2012).

Devido à sua ampla trajetória de produção do lugar, de convivência e de conhecimento das regras da sociabilidade local, permitindo a identificação dos fatores sociais que mais pesam na vida do homem comum com o qual se identifica, o idoso que vivencia um desastre tem muito que dizer sobre os acontecimentos. No trabalho de rememoração do desastre vivido realizado por esse sujeito-idoso, processam-se conjuntamente os elementos componentes e os significados atribuídos ao sofrimento coletivo e ao seu próprio sofrimento individual, além daqueles elementos e significados referentes às respectivas estratégias de resistência nessas adversas circunstâncias.

Entretanto, nos diversos contextos nacionais, incluindo o brasileiro, o desastre retratado por meio da vocalização oficial se apresenta como a compreensão unívoca do "real”, a qual dificilmente aceita reconhecer e agregar outras dimensões dos acontecimentos que porventura brotem da vocalização dos grupos sociais que vivenciam os acentuados agravos gerados pela situação, entre eles o subgrupo de idosos. Dessa desautorização, surge um abismo quase que intransponível entre as medidas de resposta e de recuperação - que o Estado supõe que sejam corretas e adequadas adotar em tais circunstâncias -, e o amparo que almejam receber os grupos em maior desvantagem social cuja afetação material e social foi severa. Esse abismo caracteriza a crise crônica, isto é, o processo de desfiliação social desses grupos, o qual - apesar da flagrante desumanização subjacente que se reflete na 
difícil superação dos agravos sofridos -, adquire crescente invisibilidade ante a opinião pública devido à concepção oficial de que o desastre ficou estancado num dia do passado e que, portanto, foi um acontecimento que já passou. A fase aguda de um desastre costuma ganhar ares de uma tragédia na qual, devido à repercussão midiática, a forma de atuação pública ganha visibilidade e aparenta grande engajamento do quadro técnico estatal para permitir que os danos e os prejuízos comunitários sejam remediados. Porém, não raro, com o passar das semanas e dos meses, a soma do desinteresse da grande mídia e das ações insuficientes do Estado impõe uma nova fase ao desastre, quando os que mais sofreram ainda têm demandas e, contudo, ficam relegados à própria sorte, abandonados, por assim dizer. É nesse processo, de tempo longo, que mais se identifica a existência de um efeito social desaglutinador (EYRE, 2007), por revelar relações de poder que comprometem ou dificultam a reorganização de uma parte relevante das rotinas da vida cotidiana de uma parcela da sociedade local.

A fabricação social de abismos como esses também suscita formas de resistência comunitária em prol da sua reumanização, tal como através da mobilização local para a retomada, noutras bases - por vezes, mais precárias -, de práticas rituais, como festas comemorativo-religiosas nas quais a comunidade recupera a memória sobre si mesma a fim de se reinventar.

Desastres só ocorrem se há um meio social envolvido (QUARANTELLI, 1998) e, portanto, atravessam o universo cultural do lugar no qual o modo de ser de cada indivíduo nele inserido está alicerçado. Como a memória social apresenta-se como uma relação fronteiriça entre o modo de ser do indivíduo e de sua cultura (BOSI, 1979), a lembrança seletiva do idoso sobre os acontecimentos não lhe pertence unicamente. Isto é, por mais que haja uma individualização da experiência de um desastre vivido, a lembrança passa pelo filtro cultural local que tanto dá a dimensão de sua humanidade quanto a situa no processo social que enseja a sua paulatina desfiliação. Apesar disso, há lembranças que se amparam demasiado na memória institucional, o que pode ser chamado de processo de estereotipia, fundado em temores e receios que, por seu turno, sinalizam o processo de desagregação social subjacente. Por isso, é importante adentrar naquilo que Pollak (1989) denomina como memórias subterrâneas, que consistem nas memórias que estão à margem da memória dita oficial.

Há uma tendência de aumento da presença de idosos em contextos de desastres (VIANA et. al., 2013) e, frente a isso, é preciso considerar algumas especificidades do processo de vulnerabilização em que estão envolvidos. Processos de vulnerabilização dizem respeito às relações políticas que tornam os sujeitos sociais vulneráveis. Os idosos se caracterizam, em termos biopsicossociais, como os mais vulnerabilizados nos desastres, pois apresentam maior probabilidade de óbito e adoecimento nessas circunstâncias (WHITTINGTON, 2010). No ano de 2005, no desastre ocorrido em Nova Orleans, nos Estados Unidos, relacionado à passagem do furacão Katrina, 73\% dos mortos tinham mais de 60 anos, embora esse grupo compreendesse menos que 15\% da população local, segundo o US Senate Comitee on Health, Education, Labor and Pensions (GIBSON, 2006).

Alguns aspectos que tornam a vulnerabilidade dos idosos desproporcional à vulnerabilidade dos adultos são as doenças crônicas, as limitações funcionais e as dis- 
funções sensoriais físicas e cognitivas, salienta Gibson (2006). Devido a essas fragilidades relacionadas à saúde física e mental, os idosos podem apresentar dificuldades e limitações para se protegerem devidamente e assegurarem a sua sobrevivência mais imediata, razão pela qual pode ser mais acentuado o seu estresse na vivência dos acontecimentos, assim como podem ser mais intensos neles os sentimentos de tristeza com a perda e com a danificação de sua propriedade imóvel e de outros bens (ORIOLL, 1999).

Em pesquisas anteriores, que comparavam os danos dos idosos com os ocorridos com os jovens, foi constatado que as pessoas idosas afetadas nos desastres perceberam as perdas havidas de forma mais aguda do que os demais (FRIEDSAM, 1961 apud NGO, 2001). Ngo destaca os estudos de Poulshock e Cohen $(1975 ; 1977)$ que retrataram o desastre na localidade de Luzerne County, na Pensilvânia, nos Estados Unidos, no ano de 1972, onde uma enchente foi seguida da passagem do furacão Agnes, resultando numa sequência de deslocamentos involuntários até que os moradores pudessem retornar às suas moradias e recuperar os danos que ali se apresentavam. Segundo o referido estudo, os moradores idosos sofreram mais acentuadamente do que os demais grupos etários. Aqueles que não tinham uma rede de apoio para alojá -los provisoriamente tiveram que ficar em abrigos temporários e, em relação aos demais, apresentaram mais nervosismo, pesadelos e depressão.

Tais considerações, que aludem a uma fragilização mais acentuada do subgrupo de idosos frente aos demais subgrupos, desatendidos ou mal-atendidos pelo ente público num contexto de desastre - somadas a uma trajetória de vida na qual, de modo geral, as- pira-se a reduzir os sobressaltos em sua vida cotidiana -, permitem-nos supor que o processo de desumanização pelo qual passam nessas circunstâncias tenha grande consistência em seus relatos, quando proferidos.

\section{Os desastres no Brasil e a visão oficial so- bre o desastre em São Luiz do Paraitinga/SP}

A missão institucional da Defesa Civil consiste na redução dos desastres no país, fazendo-o por meio de ações de prevenção, preparação, resposta e recuperação (BRASIL, 2012). Na visão institucional, os desastres são defınidos como sendo o

resultado de eventos adversos, naturais ou provocados pelo homem, sobre um ecossistema vulnerável, causando danos humanos, materiais e ambientais e consequentes prejuízos econômicos e sociais. A intensidade de um desastre depende da interação entre a magnitude do evento adverso e a vulnerabilidade do sistema e é quantificada em função de danos e prejuízos (BRASIL, 2000, p. 8).

No que diz respeito à decretação de emergência, os desastres são caracterizados pelo Sistema Nacional de Proteção e Defesa Civil (SINPDEC) de duas formas, a saber: a situação de emergência (SE), que consiste no "reconhecimento legal pelo poder público de situação anormal, provocada por desastre, causando danos suportáveis à comunidade afetada" (BRASIL, 2000, p. 9), e o estado de calamidade pública (ECP), que seria o "reconhecimento legal pelo poder público de situação anormal, provocada por desastre, causando sérios danos à comunidade afetada, inclusive à incolumidade ou à vida de seus integrantes" (BRASIL, 2000, p. 9).

Tal tipologia parte, assim, da concepção de desastre como um acontecimento so- 
cioambiental que resulta em anormalidade nas rotinas de uma dada comunidade, através da ocorrência de danos quantificáveis e de intensidades variadas, cujo limite superior seria a concretização de danos diretos e severos à vida humana, como mortes, adoecimento coletivo ou ferimentos graves em inúmeras vítimas.

0 documento oficial que detalhava determinados aspectos de danos e prejuizos numa localidade em contexto de desastre, até o ano de 2011, denominava-se Avaliação de Danos (Avadan). Nele, a natureza do desastre era identificada segundo as opções fornecidas pelo Código de Desastres, Ameaças e Riscos (Codar). No Avadan, os danos distinguiam-se em: danos humanos, focalizando os afetados, ${ }^{1}$ em geral, e alguns subgrupos, em particular - afetados estes que são referidos, no documento em tela, como desalojados, ${ }^{2}$ desabrigados, ${ }^{3}$ desaparecidos, ${ }^{4}$ mortos e feridos -, e distribuídos em três faixas etárias e pela condição de gestante; danos materiais, com foco nas edificações residenciais e públicas; danos com foco na infraestrutura pública e nos danos ambientais, envolvendo recursos como a água, o solo, o ar, a fauna e a flora. Esse documento elencava, ainda, dois tipos de prejuizos, quais sejam, os prejuizos econômicos - referentes às perdas materiais e financeiras na atividade local dos setores primário, secundário e terciário - e os prejuizos sociais, focalizando quantidades e valores monetários de serviços essenciais interrompidos na circunstância do desastre.

Embora essa tipologia de danos e de prejuízos - com subgrupos discriminados isoladamente e privilegiando a informação de base quantitativa - dê pistas relevantes acerca do panorama mais geral das condições socioambientais e socioeconômicas comunitárias perturbadas por um desastre, ela não contempla importantes conexões; dentre elas, as existentes entre os indivíduos distribuídos nos diversos subgrupos. Isso invisibiliza os laços familiares, de parentesco ou de vizinhança, a conexão dos indivíduos com as moradias danificadas ou destruídas e também a sua relação com as atividades econômicas e os serviços essenciais públicos prejudicados, dentre outros. Significa dizer que o Avadan se caracterizava como um documento que fracionava a realidade concreta, norteando, por seu turno, ações setoriais igualmente autônomas e, por vezes, incongruentes e descompassadas. Essa desconexão explica, em parte, as dificuldades para viabilizar o pleno restabelecimento da vida cotidiana comunitária nos moldes anteriores à ocorrência do desastre. Ilustrativamente, num Avadan de um dado município, o caso de uma gestante adolescente que porventura tivesse seu companheiro desaparecido na ocorrência, com outros filhos feridos, a mãe idosa

1. 0 afetado é considerado como "qualquer pessoa que tenha sido atingida ou prejudicada por desastre (deslocado, desabrigado, ferido etc.)" (CASTR0, 1999, p. 8).

2. De acordo com o Glossário de Defesa Civil, desabrigado é o "desalojado ou pessoa cuja habitação foi afetada por dano ou ameaça de dano e que necessita de abrigo provido pelo Sistema” (Ibidem, p. 52).

3. A categoria técnica de desalojado pode ser compreendida como a "pessoa que foi obrigada a abandonar temporária ou definitivamente sua habitação, em função de evacuações preventivas, destruição ou avaria grave, decorrentes do desastre, e que, não necessariamente, carece de abrigo provido pelo Sistema" (Ibidem, p. 52).

4. Desaparecido consiste na "pessoa que não foi localizada ou de destino desconhecido, em circunstância de desastre” (Ibidem, p. 52). 
adoecida e a sua moradia destruída, num bairro que apresentasse uma infraestrutura originalmente precária - que, ainda por cima, tivesse sofrido danificação no episódio - constitui as especificidades de um drama social que o Avadan, por si mesmo, não permitia verificar. 0 documento apenas permitia a presunção de que os grupos sociais mais severamente afetados tivessem uma relação entre si, e com as moradias e os bairros mais prejudicados. Desafortunadamente, os novos instrumentos da Política Nacional de Proteção e Defesa Civil, vigente desde o ano de 2012 - a saber, o Formulário de Informações do Desastre (Fide) e a Classificação e Codificação Brasileira de Desastres (Cobrade), que substituíram o Avadan e o anterior Código de Desastres, Ameaças e Riscos (Codar), sintetizaram e reduziram ainda mais a apreensão da realidade concreta de um desastre e persistiram na mesma lógica de fracionamento de seus elementos constituintes (VALENCIO, 2014b). Por seu turno, as práticas de cadastramento das famílias afetadas nos desastres, as quais são realizadas pelos técnicos de assistência social, não têm conseguido dar conta de identificar os panoramas socioambiental, socioeconômico e sociopolítico mais amplos nos quais se situam os anseios de proteção do conjunto de membros das famílias e das comunidades às quais essas famílias estão identitariamente vinculadas, e tampouco deflagram as providências públicas pertinentes (SIENA, 2012).

Os desastres relacionados à água no Brasil, seja por stress hídrico ou pelas chuvas intensas, representam aproximadamente 90\% do total dos desastres atestados pelas autoridades competentes, isto é, aqueles desastres que geraram decretos municipais de situação de emergência (SE) ou estado de calamidade pública (ECP) seguidos de portaria ministerial de reconhecimento (VALENCIO; VALENCIO, 2010). No período de janeiro de 2003 a dezembro de 2013, foram publicadas 20.766 portarias de reconhecimento de SE e $\mathrm{ECP}$, que ratificaram os respectivos decretos municipais de emergência ou calamidade pública. No universo de 5.565 municípios brasileiros, essa soma de SE e ECP é preocupante, pois sinaliza uma disseminação dessa crise e sua recorrência em algumas localidades, denotando a preocupante incapacidade pública para compreender e atuar de maneira socialmente mais apropriada diante desse tipo de crise.

Um quarto dos desastres relacionados à água tem relação com chuvas concentradas ou prolongadas. Milhões de pessoas têm sido afetadas pelos desastres relacionados às chuvas no Brasil, o que envolve, na vida pública, desde a perda de infraestruturas e de acesso a serviços essenciais - com o comprometimento de vias de tráfego e de transporte, a interrupção de serviços de eletricidade, de telefonia e de abastecimento hídrico - até a perda de objetos e meios de trabalho, como veículos, plantações, animais de criação, equipamentos eletrônicos, entre outros. Há, ainda, na vida privada, a danificação ou destruição da moradia e dos bens móveis, de valor material e simbólico, ali contidos, somada, por fim, ao ferimento e adoecimento de pessoas, a mortes e a desaparecimentos. Do primeiro semestre de 2007 ao primeiro semestre de 2010 , foram 22.089.804 pessoas afetadas por esse tipo de desastre no país, segundo os registros oficiais (VALENCIO; VALENCIO, 2010), o que equivale a aproximadamente um décimo da população total do país.

A região Sudeste agrega 1.668 municípios, com 53.078.137 habitantes, e consiste na região mais populosa do país (IBGE, 2010). No estado de São Paulo, no período 
de 1991 a 2010, e de acordo com os dados do Atlas Brasileiro de Desastres Naturais (2011), houve 3.743.793 de pessoas afetadas em desastres relacionados às chuvas e aos seus efeitos, especificamente inundações bruscas. Dentre elas, 17 pessoas ficaram gravemente feridas, 48 ficaram desaparecidas, 485, levemente feridas, 1.034, enfermas, 153, mortas, 63.653, desabrigadas, 63.133, deslocadas e 92.284, desalojadas.

São Luiz do Paraitinga foi um dos municípios paulistas em que o desastre mostrou a sua feição mais severa.

\subsection{0 desastre em São Luiz do Paraitinga: informações oficiais}

0 município de São Luiz do Paraitinga é uma estância turística e está localizado na região do Vale do Paraíba, na parte leste do estado de São Paulo, na latitude $23^{\circ}$ 22' e na longitude $45^{\circ} 31^{\prime}$. O bioma local é o da Mata Atlântica, apresentando clima temperado. A região, situada entre a Serra da Quebra-Cangalha e o topo da Serra do Mar, encontra-se na sub-região do Alto $\mathrm{Pa}$ raíba, caracterizada geograficamente como um mar de morros, por ser uma região de montanhas e poucas várzeas que definem sua paisagem física (CAMPOS, 2011).

0 municipio possui 10.397 habitantes, dos quais 59,44\% vivem em áreas urbanas e 40,56\% moram em áreas rurais. A área total do município é de $617,15 \mathrm{~km}^{2}$, resultando em 16,84 hab./ $\mathrm{km}^{2}$ (IBGE, 2010). Do número total de habitantes, 51,15\% são homens e 48,85\% são mulheres (PNUD, 2013). A porcentagem de idosos em relação à população total luizense é de 15,37\%, maior do que a de idosos no Brasil, que representa 10,79\% em relação ao total (IBGE, 2010). De acordo com o Atlas de Desenvolvimento Humano (2013), a taxa de envelhecimento no município aumentou de $6,37 \%$ para $11,08 \%$ no período de 1991 a $2010 .^{5}$

No período de 2006 a 2010, 6 em São Luiz do Paraitinga, 19.760 pessoas foram afetadas por desastres relacionados às chuvas - ocasionando enchentes e deslizamentos de terra em área habitada -, o que permite considerar, no universo de 10.397 habitantes, que muitos deles são moradores locais afetados mais de uma vez em um curto espaço de tempo, além de parte da população flutuante, principalmente os turistas (Tabela 1). Os afetados foram distribuídos, nos respectivos Avadan, nos subgrupos de desalojados, desabrigados, deslocados e desaparecidos. Os desastres ocorridos nos anos de 2006, 2008 e 2009 foram decretados como situação de emergência, e o desastre ocorrido no ano de 2010 foi decretado pela autoridade municipal como estado de calamidade pública.

5. A taxa de envelhecimento é a razão entre a população de 65 anos ou mais de idade e a população total (PNUD, 2013).

6. A seleção do período de 2006 a 2010 refere-se aos danos humanos mencionados e deu-se em razão de não estarem disponiveis, no site do Ministério da Integração Nacional, os documentos de Avaliação de Danos (Avadan) dos anos anteriores. 
Tabela 1 - Número total de pessoas afetadas nos desastres no município de São Luiz do Paraitinga-SP, no período de 2006 a 2010.

\begin{tabular}{lcccc}
\hline & 2006 & 2008 & 2009 & 2010 \\
Desalojados & 7 & 18 & 61 & 4.030 \\
Desabrigados & - & $\mathrm{X}$ & 20 & 93 \\
Deslocados & 600 & 710 & - & 16 \\
Desaparecidos & 1 & - & - & - \\
Afetados & 2.990 & 3.252 & 2.518 & $11.000\left(^{*}\right)$ \\
\hline
\end{tabular}

Fonte: Elaboração própria, com base em informações do documento Avadan (2006; 2008; 2009; 2010).

(*) 0 número de afetados em relação à população do município é maior devido à soma de residentes com a população flutuante afetada na ocasião do desastre mencionado.

0 número total de afetados no desastre ocorrido no ano de 2010 foi mais que o triplo do contabilizado nos anos anteriores, acentuando-se significativamente a situação de desalojamento, o que - devido à insuficiência das medidas públicas adotadas - exigiu a acolhida de muitas das famílias por sua rede primária de apoio. Em relação aos danos humanos havidos, o nú- mero total de afetados nessa inundação foi de 11.000 pessoas, das quais 4.030 ficaram desalojadas, 93, desabrigadas e 16 foram deslocadas. Dentre os afetados nesse desastre, 1.172 eram idosos, ${ }^{7}$ o que corresponde a 10,65\% em relação ao total de afetados. Desses idosos, 508 ficaram desalojados, 8 ficaram desabrigados e 16 foram deslocados (Quadro 1).

Quadro 1 - Danos humanos referentes ao desastre ocorrido em São Luiz do Paraitinga no ano de 2010.

\begin{tabular}{lccccc}
\hline $\begin{array}{l}\text { Danos humanos - } \\
\text { Número de pessoas }\end{array}$ & $\mathbf{0}$ a 14 anos & $\begin{array}{c}15 \text { a } 64 \\
\text { anos }\end{array}$ & $\begin{array}{c}\text { Acima de } 65 \\
\text { anos }\end{array}$ & Gestantes & Total \\
Desalojadas & 1160 & 2360 & 508 & 02 & 4030 \\
Desabrigadas & 31 & 52 & 08 & 02 & 93 \\
Desaparecidas & 0 & 0 & 16 & 0 & 16 \\
Levemente feridas & 0 & 0 & 0 & 0 & 0 \\
Gravemente feridas & 0 & 0 & 0 & 0 & 0 \\
Enfermas & 0 & 0 & 0 & 0 & 0 \\
Mortas & 0 & 0 & 1172 & 82 & 11000 \\
Afetadas & 2018 & 7728 & & 0 & 0 \\
\hline
\end{tabular}

Fonte: Prefeitura Municipal de São Luiz do Paraitinga (Avadan, 2010).

7. Vale ressaltar que o recorte etário feito no Avadan considera pessoas acima de 65 anos, enquanto o Estatuto do Idoso considera idosa a pessoa acima de 60 anos. Ou seja, o número de idosos afetados é maior do que o que foi destacado no Avadan. 
Em linhas gerais, a forma como a autoridade municipal descreveu o desastre de 2010 no Avadan foi a seguinte: o acontecimento teria se caracterizado como uma enxurrada ou inundação brusca (no âmbito do código de desastres anteriormente vigente, o Codar, correspondia ao código NE. HEX 12.312), deflagrada às oito horas do primeiro dia do referido ano. A causa mencionada pelas autoridades públicas para justificar a concretização do desastre foi a chuva concentrada no mês de dezembro (600 mm), com um pico no dia $1^{\circ}$ de janeiro, o que teria levado ao transbordamento os principais rios da região. 0 padrão evolutivo do desastre foi considerado como gradual, porém, imprevisível, com tendência a agravamento. Além dos danos humanos mencionados na figura acima (Figura 1), o referido documento aludiu a uma extensa quantidade de danos e prejuízos, dos quais se destacaram: a danificação de 112 residências e destruição de outras 44; a danificação de $200 \mathrm{~km}$ de estrada e destruição de outros $15 \mathrm{~km}$; na atividade econômica, ocorreu a danificação de 225 estabelecimentos comerciais e destruição de 05, somadas a perdas de 100 toneladas de grãos, 150 mil litros de leite e 3 mil aves de criação; nos serviços essenciais, constatouse a alta intensidade de dano nos esgotos sanitários e a danificação de uma estação de tratamento de água, além da intensidade muito alta de dano relativo ao solo (deslizamentos, erosão e contaminação); 4.680 consumidores ficaram sem energia elétrica; foram danifıcadas 10 redes de comunicação, assim como 01 estação retransmissora; dentre outros.

No entanto, as conexões socioespaciais entre tais danos e prejuízos não ficou estabelecida diretamente no referido documento devido à segmentação em que as in- formações são ordenadas. Desse modo, os registros oficiais não se prestavam para que o público em geral pudesse compreender, de pronto e de forma integrada, a situação crítica que estancava a vida cotidiana da comunidade luizense.

Apesar de o documento trazer uma descrição qualitativa complementar dos prejuízos sociais - aludindo a problemas relacionados à vulnerabilidade social, à proteção dos direitos da pessoa humana (da moradia à saúde e educação), além de mencionar a destruição de patrimônio histórico que servia à manutenção da identidade social local, com os danos psicossociais decorrentes -, o que sobressaiu foi a insuficiência das providências públicas tomadas. Isso se constata através das nuances da crise reveladas através dos relatos dos idosos imersos nela, conforme veremos a seguir.

\section{0 desastre vivenciado}

De acordo com o Estatuto do Idoso, é considerado idoso o indivíduo com idade igual a ou maior que sessenta anos (BRASIL, 2003). Segundo esse Estatuto, é dever do Estado garantir a vida e a saúde da pessoa idosa. A Lei 10.741 , de $1^{\circ}$ de outubro de 2003, Art. $2^{\circ}$, destaca que o idoso

[...] goza de todos os direitos fundamentais inerentes à pessoa humana, sem prejuízo da proteção integral de que trata esta Lei, assegurando-se-lhe, por lei ou por outros meios, todas as oportunidades e facilidades, para preservação de sua saúde física e mental e seu aperfeiçoamento moral, intelectual, espiritual e social, em condições de liberdade e dignidade (BRASIL, 2003, p. 1).

Sob tal prisma, viver um desastre, pelas mais diversas dimensões de perdas e 
danos - isto é, no âmbito da família, da casa, do trabalho, dos bens comunitários e do valor sentimental em torno dos objetos danificados ou destruídos, dentre outros implica, fundamentalmente, ver desmoronar as condições de liberdade e dignidade que menciona a referida lei. Na perspectiva harendtiana, o homem privado do acesso às coisas e relações essenciais, imerso no reino da necessidade, não vive em plena liberdade para realizar ou reafirmar a sua condição humana.

No caso dos moradores idosos de São Luiz do Paraitinga, o sofrimento multidimensional pelas perdas vividas encontrou a face desumanizante do desastre, de um lado; mas, de outro, formas miúdas de resistência também reelaboram uma vida social plausivel. Para Alfredo Bosi, "resistir é opor a força própria à força alheia” (BOSI, 2002, p. 118), mover-se por valores acima das circunstâncias eventualmente adversas. Todavia, há os que sofrem de modo a naturalizar as injustiças sociais que são praticadas contra si, reduzindo a compreensão da situação à sua própria culpa e incapacidade, não resistindo à força alheia como deveriam e, assim, seguem mutilados na condição de exercitar a sua cidadania (SANTOS, 1997).

Alfredo Bosi (2002) faz, ainda, uma pertinente contraposição entre a poesia $d a$ existência, pautada nos conceitos da arte, e a narrativa da existência, que é elaborada por meio da ética e política. No entanto, essas se imbricam, posto que "como sempre acontece, no fazer-se concreto e multiplamente determinado da existência pessoal, fios subterrâneos poderosos amarram as pulsões e os signos, os desejos e as imagens, os projetos políticos e as teorias, as ações e os conceitos” (BOSI, 2002, p. 119).

Seria deveras complexo, senão mesmo pretensioso, supor a possibilidade de ex- pressar, com o vigor apropriado, a memória social de idosos acerca de dimensões socioeconômicas, socioculturais e psicossociais do sofrimento coletivo havido no desastre em tela. Ademais, esse sofrimento não pode ser expresso apenas por palavras, pois é vivenciado associativamente ao corpo, às feições, aos olhares, aos gestos, aos sentimentos e à atmosfera do ambiente de quem o relata. Disso decorre que os excertos dos relatos abaixo apresentados sejam apenas indícios de uma memória social acerca da experiência humana mais rica (e desafiadora) de imersão nas fases aguda e crônica da crise, mas que permitem identificar sua distinção em relação à narrativa oficial, e esse é o propósito central de trazê-los aqui. Ademais, há reentrâncias indiziveis da vida social que se manifestam através dos silêncios havidos entre uma e outra vocalização pessoal de aspectos das lembranças compartilhadas, através da voz embargada do narrador em torno deste ou daquele trecho do seu ato de rememorar ou, ainda, da negação do seu sofrimento num contexto espacial privado em que é possível observar a existência de uma significativa precariedade material e social.

Durante a realização do trabalho de campo, através da coleta de relatos orais, associada à observação de algumas rotinas comunitárias luizenses - identificadas com um modo de vida caipira e com sua característica prática de acolhimento -, pudemos estabelecer interações relativamente aleatórias com 13 idosos (sendo 7 mulheres e 6 homens), residentes em diferentes áreas do município. Referimo-nos a essa relativa aleatoriedade porque tanto os registros oficiais como os hemerográficos reportavam as regiões da cidade mais afetadas em termos de moradias danificadas ou destruídas. Dentre os bairros mais 
afetados, destacamos o Centro Histórico do município, Várzea dos Passarinhos, Ver de Perto e Benfica - sendo os dois primeiros os mais danificados. Isso orientou a pesquisa no concernente aos locais onde as coletas deveriam ser realizadas. Uma vez ali estando, a abordagem aos moradores locais somente em parte foi direcionada e, em outra parte, esteve ao sabor das circunstâncias. Foi direcionada quanto ao propósito de se procurar por idosos, num esforço adicional por se manter um balanço de gênero. Todavia, foi aleatória na medida em que não se podia prever nem controlar quem seriam as pessoas que transitariam no lugar quando ali estávamos, e se se encaixariam nesse recorte etário e de gênero; isto é, a configuração de encontro não foi intencional. $\mathrm{Na}$ medida em que, no contato inicial travado, se confirmava ser aquele o seu lugar de residência e que a pessoa abordada esteve envolvida, de forma multidimensional, naquele acontecimento trágico - isto é, não apenas a sua moradia tinha sofrido agravos materiais, mas ela própria estava presente na ocasião e tinha vivido os demais percalços daquela crise aguda - era-lhe indagado se porventura tinha disposição e disponibilidade para conceder uma entrevista. Dentre todas as 13 pessoas abordadas, houve uma recusa inicial de uma idosa que, após observar a disposição de outros conhecidos seus que se ofereceram de bom grado para essa interação, acabou por assentir. Assim, não foi constituído um grupo a priori para externar uma memória coletiva. A memória comum que se buscou através de memórias pessoais não o exigia.

Visto que esta pesquisa visou a trazer à tona a riqueza de detalhes que constituiu a memória pessoal naquilo que, gradualmente, a enfeixava a uma memória comum de idosos assaz dissonante da de caráter oficial
- e essa dissonância era o foco central -, os nomes dos entrevistados não foram divulgados, com o intuito de preservar suas identidades. Ademais, a garantia de anonimato fez parte dos critérios de consentimento oral no contexto de coleta da informação. A opção por manter os informantes em anonimato foi planejada, antes da ida ao campo, devido ao propósito de ressaltar esse conjunto mais amplo de sentidos de vivência de um desastre e do que teria sido, alternativamente, deter-se na trajetória mais aprofundada dos informantes e sua respectiva história de vida. Porém, o que mais fortemente nos orientou para a decisão de planejar a pesquisa evitando a nominação de cada um dos informantes foi a intenção de protegê-los de um risco de retaliação, uma vez que sua narrativa de sofrimento poderia ser eventualmente tomada como uma crítica às práticas dos quadros técnicos que atuaram naquela circunstância e que eram formados, essencialmente, por militares (da Defesa Civil Estadual, que é, de fato, um braço operacional da Polícia Militar, da própria Polícia Militar e das Forças Armadas) e técnicos de assistência social. Conforme assinalado por Marchezini (2015), o caso do desastre em São Luiz do Paraitinga denotou uma flagrante manifestação de uma biopolítica; isto é, havia certos sujeitos em posição de comando, sobretudo militares, e os dispositivos por eles deflagrados (interrogatórios, birôs de caridade, interdições territoriais, impedimentos aos recursos de voz locais) construíram relações de submissão da comunidade afetada, inclusive através da prática de se ter armas em punho e da imposição de uma nova ordem de rotinas comunitárias. Desse modo, a própria concepção de democracia, como contexto passível à oposição de ideias, sofreu ameaça nessas circunstâncias. Por fim, mas não menos importante, o Código 
de Ética da Sociedade Brasileira de Sociologia recomenda que, na comunicação de resultados de pesquisa, devem-se proteger os direitos dos informantes através de formas de precaução, como a confıdencialidade, sobretudo se houver riscos implicados a eles em sua identificação pessoal.

Com pequenas nuances, as narrativas dos idosos replicaram a mesma cena do que eles consideravam como sendo o início do desastre. Assim se referiu o Entrevistado A, abaixo:

Foi na passagem de 31 de dezembro de 2009 para $1^{\circ}$ janeiro de 2010. Estava tendo uma festa no coreto, comemorando o Ano Novo, e estava chovendo muito. Naquele ano, choveu demais da conta e tem o ribeirão do Chapéu, a mais ou menos $2 \mathrm{~km}$ daqui, um afluente do rio [Paraitinga]. Quando chove muito, desce uma enchente muito rápida e muito forte $\mathrm{e}$ ela atravessa o rio e represa a água do rio $\mathrm{Pa}-$ raitinga. 0 rio é pequeno e acaba represando. Todas as vezes que chove muito em São Luiz, é umas seis horas de enchente, que vem de baixo pra cima. E, dessa vez, começou em Cunha e deve ter caído uma tromba d'água. Eu nunca vi tanta água daquele jeito, nunca na vida. Ficou quatro dias aqui na cidade. Aí, quando estava aqui no Réveillon, eu vi que a chuva era uma chuva branca da serra [...] Quando foi umas duas ou três horas da manhã, ele começou a baixar, e aí começou a chegar a enchente de Cunha. E aí veio muita água, muita água, e além de estar represado, veio empurrando, só que, aí, o ribeirão abaixou e a água continuou, subiu até a ponta do Coreto. Quando eu consegui vir pra cá, ver o que estava acontecendo, já era 10 horas da manhã, [...] já estava tudo cheio, a igreja já tinha caído umas partes, já tinha caído a torre, e todo mundo correu pra cima [...] Aí a água foi a abaixando aos poucos, quando foi baixando, a gente não tinha mais a igreja, e nem a Capela das Mercês, e o casarão, nem a escola aqui [...] E o que aconteceu também foi que logo depois no terceiro dia, no dia três de janeiro, caiu um barranco perto de casa, e aí desceu o morro inteiro, foi onde morreu uma pessoa, meu primo, ele estava passando abaixo da estrada, e também a gente não conseguia passar pela estrada, então eu vinha pelo alto do morro. Foi muito difícil por que a gente não tinha onde comprar as coisas. A geladeira não funcionava, porque acabou a eletricidade. [...] A maior perda foi o patrimônio da cidade, pois não vai ser mais igual. Você olhava a pracinha era uma coisa muito linda, as casas todas coloridas. Agora você olha ali e já olha com sentimento. A igreja foi a maior perda, eu acho. Tinha o relógio, e de vez em quando a gente se pega olhando pro relógio pra ver as horas. Todo mundo olhava pro relógio pra ver a hora. [...] Não caiu a ficha direito. Era o ponto de encontro, sabe? (informação verbal ${ }^{8}$ ).

0 relato inicial do entrevistado A dá ênfase, preliminarmente, a um dos principais marcadores espaço-temporais locais da intersecção entre a vida cotidiana e o desastre, qual seja, as festividades do novo ano, que levaram o povo local a confraternizar ao derredor do coreto (na praça central da cidade). A passagem para o dia $1^{\circ}$ do ano 2010 aludia aos recomeços coletivos, à esperança coletiva num futuro melhor, o que levou as pessoas a adentrarem a madrugada em comemorações e, depois, dormirem despreocupadas. A chuva forte, em si mesma, não era um fator inusual de preocupação. Os luizenses sabiam que o problema

8. Entrevistado A, Zona Rural, julho de 2012, grifo nosso. 
maior eram os riscos envolvidos na capacidade dos mananciais da bacia, no nível regional, absorver o volume precipitado, isto é, riscos de extravasamento da calha principal de rios e ribeirões locais com efeitos ambientais nocivos, como os de enchentes. A convivência com enchentes também é mencionada nos relatos, assim como a prática usual de observação dos mananciais. 0 povo local apresenta o costume de estimar o período em que a enchente se inicia e acaba, bem como os danos esperados e as fronteiras físicas da danificação.

Um dos aspectos que transformou essa enchente numa calamidade foi um volume concentrado de água no perímetro urbano, o que, quebrando as fronteiras conhecidas das enchentes anteriores, levou a maioria dos moradores da cidade a priorizarem "correr pra cima” - isto é, abandonarem subitamente as suas moradias, em vez de acudir suas coisas, como antes se fazia - muito embora, para os idosos, cuidar de sua moradia e bens de valor simbólico e sentimental ainda tivesse se mantido como algo vital.

Toda a população local, inclusos os idosos, testemunhou a destruição de dois dos maiores ícones da cultura luizense, a saber: a Igreja Matriz e a Capela das Mercês; em relação a tal ocorrência, os idosos sofreram muito. Tais espaços não eram considerados localmente apenas como patrimônio histórico que, somado aos casarões e ao mercado central, permitiu o desenvolvimento de uma atividade turística próspera nas últimas décadas. Eram parte da identidade luizense, profundamente religiosa, que organizava o modo de vida local, desde as interações comunitárias mais frequentes e significativas até as rotinas da vida prática. 0 sino da Igreja Matriz, por exemplo, era o que cronome- trava a vida prática no núcleo urbano e dava a orientação comunitária do tempo.

No ano de 1982, o Conselho de Defesa do Patrimônio Histórico, Arqueológico, Artístico e Turístico do Estado de São Paulo (Condephaat) tombou diversas obras arquitetônicas da cidade; dentre elas, os grandes casarões que estão localizados na praça central da cidade, a Igreja Matriz, a Igreja do Rosário e a Capela das Mercês (esta construída em 1806 e inaugurada em 1814). No desastre de 2010, grande parte dessas obras foi total ou parcialmente destruída devido a serem construções à base de taipa, suscetíveis a abalos em sua estrutura ao contato com grandes volumes de água.

A Capela das Mercês foi a primeira igreja a ser reconstruída e inaugurada em setembro de 2011. Na primeira inserção em campo, no mês de julho de 2012, observamos que a reconstrução dessa capela parecia ser um alívio para os idosos que supunham que não estariam mais vivos para a verem novamente erigida. Maior alívio, todavia, seria poderem testemunhar a reinauguração da Igreja Matriz. Uma enfermeira, da Instituição de Longa Permanência para Idosos (ILPI), informou-nos desse receio dos idosos:

Muita gente diz que nunca mais vai ver a igreja ficar pronta. Eu falo 'não gente, calma! No ano que vem'. Mas, eles dizem 'ah, mas será que eu vou aguentar esperar?' Eu falo: 'claro que vai! Que é isso, vocês não podem pensar assim'. Eles acham que nunca mais vão ver uma casa naquele lugar vazio, nunca vai ver a igreja. Aí eu digo: 'a Capela das Mercês não caiu e ela já não esta em pé? Então tem que ter calma e paciência. Se Deus quiser, vai ver sim!' (informação verbal ${ }^{9}$ ). 
E, em seguida, relatos de idosos não institucionalizados, como o da entrevistada J, confirmam:

[...] se a igreja caiu faz mais de 3 anos, e não acabou? É muito devagar! [...] Falaram que vai demora 7 anos pra fazer, eu não sei se vivo pra ver, que eu já estou com quase 70 anos (informação verbal ${ }^{10}$ ).

Práticas religiosas ritualizadas cotidianas de luizenses idosos eram conduzidas no uso do espaço dos referidos estabelecimentos. Assim, quando em seu relato o idoso B fala “não aguentei ver aquilo”, ou o idoso L destaca "a gente estava sentindo aquilo, e a gente não queria nem olhar”, ambos indicam que o testemunho da destruição súbita dos referidos estabelecimentos religiosos foi emocionalmente intenso, pois se tratava de um aspecto importante da sua vida social que se ruía. 0 relato da entrevistada $\mathrm{J}$ igualmente enfatiza:

Eu fui lá, quando eu vi caindo, deu um negócio tão ruim, que eu não ia ficar vendo essas coisa não. Foi caindo, caiu a torre... Passa aquela imagem, reprisa o tempo todo. Eu tava lá perto e fui embora, não aguentava ver aquilo. (informação verbal ${ }^{11}$ ).

Meu filho chegou na casa da minha madrasta e falou pra mim: 'mãe, sinto muito, mas a casa da senhora rodou'. Se rodou, também não me importo, porque a igreja, que eu que- ria que não caísse, caiu. Então, a minha casa não é nada, porque a gente ficando vivo, começa de novo [...] Eu estava na varanda da casa do meu pai, enxergava tudo, eu vi caí as casas da rua Barão; depois, caiu uma torre da igreja e, depois, desabou o resto. Nossa! Que medo! Nesse dia, eu chorei muito viu? Porque a casa da gente ia ser mais fácil levantar outra, mas a igreja, eu acho que eu morro, eu não consigo ver (informação verbal ${ }^{12}$ ).

Quando eu fui pegar o barco pra sair da minha casa, alguém gritou: 'caiu a torre da igreja!'. Eu escutei o pessoal correndo e dizendo 'caiu outro pedaço'. A gente estava sentindo aquilo, e a gente não queria nem olhar. 0 negócio é seguir pra frente (informação verbal ${ }^{13}$ ).

0 vínculo com o sagrado é comunitariamente tão significativo em São Luiz do Paraitinga que, em vez de acudir os bens privados em risco, em meio à lama e aos escombros - como veículos, eletrodomésticos e outros - muitos moradores mobilizaramse rapidamente, de forma autodeterminada, para resgatar as imagens sagradas sob os escombros dos estabelecimentos religiosos colapsados, a despeito do esforço de interdição da área pelos técnicos de defesa civil e da expectativa destes de que a preocupação dos indivíduos e das famílias com os transtornos inesperados na vida privada preponderasse. ${ }^{14}$ De fato, acudir as próprias coisas, no âmbito da vida privada, pode ser

10. Entrevistada J, Várzea dos Passarinhos, março de 2013, grifo nosso.

11. Entrevistado B, Várzea dos Passarinhos, março de 2013, grifo nosso.

12. Entrevistada J, Várzea dos Passarinhos, março de 2013, grifo nosso.

13. Entrevistado L, centro da cidade, julho de 2012, grifo nosso.

14. 0 geólogo e historiador do Instituto de Pesquisas Tecnológicas (IPT), Eduardo Macedo, socializou essa informação ao público quando de sua participação na mesa-redonda "Dinâmica social dos desastres naturais “, ocorrida na III Semana de Gestão Ambiental da EACH/USP-Leste, no ano de 2011. 
algo que tem prioridade, inclusive para os idosos, mas, por vezes, estão envolvidos fatores distintos dos que os técnicos supõem, conforme veremos mais abaixo.

Essa relação dos moradores do município com a Igreja Matriz é reforçada por Campos (2011), que destaca o fato de que:

Muitas pessoas que ficaram desalojadas, saindo apenas com a roupa que estavam usando, lamentavam mais a queda do templo do que a perda de suas casas e de seus bens. Sua reconstrução ficou, no imaginário dos moradores, como um sinal da reconstrução da cidade e de suas vidas (CAMPOS, 2011, p. 50, grifo nosso).

A relação entre o sagrado e o profano é igualmente muito expressiva na vida comunitária local. Existem rumores de que a introdução da prática comunitária de festejar o Carnaval, tornando-o uma atração pública no município, tem forte relação com esse desastre que arrancou-lhes o espaço do sagrado, sendo uma punição já intuída por um pároco, no passado, como rememora a entrevistada $\mathrm{M}$ :

0 prefeito foi eleito aqui, há alguns anos atrás, e ele trouxe o 'abençoado carnaval'. E foi depois que trouxe esse carnaval, ele trouxe a maldição pra São Luiz. Eu acho que foi isso que trouxe a maldição, porque antigamente, quando eu era criança, minha vó já falava que tinha um padre aqui em São Luiz, o padre italiano, da década de 1950 , falava que, se em São Luiz tivesse carnaval, o [rio] Paraíba ia chegar na escada da igreja. Aí, esse prefeito inventou de trazer esse carnaval porque dá dinheiro, né? Dá turis- ta, pronto! Aí, foi só desordem, eu acho que Deus mandou um aviso. A igreja foi parar tudo no chão, eu acho que foi um aviso que Deus mandou. Eu acho que, se São Luiz não melhorar, vem coisa pior, viu? (informação verbal $\left.{ }^{15}\right)$.

0 desastre é compreendido, assim, não apenas como uma relação socioambiental em que a comunidade se vê envolvida - observando a correspondência entre as águas intensamente precipitadas dos céus, depositadas em mananciais que, ocasionalmente, não lhe dão a devida vazão e invadem a área pública e privada edificada -, mas também como uma relação com o transcendental, uma punição divina à comunidade diante de sua decisão pública de utilizar uma festa pagã para atrair uma população itinerante e, com ela, fomentar a economia local. A comunidade erigida sobre uma raiz rural, centrada na atividade cafeeira, passou a ancorar-se na indústria turística nas últimas décadas. As comemorações carnavalescas de São Luiz do Paraitinga atraem muitos turistas e visitantes ao Vale do Paraíba, oriundos do eixo Rio-São Paulo, principalmente. Sendo o ápice do desastre a queda da Igreja Matriz, no imaginário social local as razões de sua queda não se relacionaram apenas com as águas volumosas e revoltas, mas imbricam-se em um fenômeno ambiental de caráter cultural.

As preocupações com a reconstrução da cidade ultrapassaram a questão da Igreja Matriz. De acordo com o entrevistado A, seria essencial manter os padrões anteriores dos casarões antigos da cidade. 0 esforço técnico para a reconstrução da cidade era bem-vindo, mas apenas na medida em que

15. Entrevistada M, Várzea dos Passarinhos, julho de 2012, grifo nosso. 
não ameaçasse modificar o centro histórico de São Luiz do Paraitinga, pois alterações que eventualmente ocorressem no plano material eram vistas como formas de violência simbólica à vida social e cultural local. Quanto a isso, o entrevistado A destacou problemas tanto na reconstrução de uma escola quanto na inauguração de um banco situado em frente à praça central da cidade:

Não sei como permitiram fazer, é tudo diferente do resto da cidade. Você olha... Colocaram a cor do Bradesco, podiam ter mantido as linhas, porque eu acho horrivel essa coisa de imitar o antigo, fica pior do que fazer moderno de uma vez. Aquele ali, fizeram de madeira, mas não tem nada a ver com São Luiz. Essa que é a minha preocupação, né? Que isso se transforme. Daqui uns dias apareça um casarão diferente ali, que não tem nada a ver [...] A biblioteca foi feita com ferro, era uma escola, aí fizeram uma coisa que não tinha nada a ver com o que era. Portão de ferro, janelas de ferro. Então a gente está brigando por isso também. Por que, se um proprietário particular tem que fazer de madeira, por que eles fizeram de ferro? A gente está questionando... Muito lindo o que fizeram dentro, mas que fosse a fachada pelo menos de madeira [...] Todo mundo tem que fazer da maneira da cidade. E, ali, eles fizeram diferente. Então, tem coisas que ficaram boas, mas tem coisas que ainda né... Imagine você, chegar na praça aqui, e ver uma cerca de tábua, parece um curral. Eu acho que eles deveriam ter dado um jeito de melhorar isso aí. Então, ainda está refletindo um pouco negativamente pra cidade, né? Tem muitas melhorias, dos morros trincados, estão arrumando a rua do Carvalho, que é mais antiga de São Luiz. Eles fizeram as encostas [...] Tem algumas coisas que precisam melhorar, mas como foi uma coisa que a gente nunca esperava, nunca aconteceu. Então a gente ainda está esperando que melhore porque essa praça era muito linda com aquele casarão... Tinham uns casarões aqui... Tem que ter um cuidado pra manter as tradições, foi feito, mas diferente. Eu tenho um DVD que mostra a escola como era, era maravilhosa, as portas eram de frente, as janelas... era outra coisa (informação verbal ${ }^{16}$ ).

As perdas materiais e imateriais referentes ao mundo público e privado se entrelaçam. Antes de nos deter nesse aspecto, convém reiterar que os luizenses tinham experiência em enfrentar enchentes, pois elas são recorrentes no município. Os moradores locais estavam habituados a colocar os seus pertences em locais mais altos e, depois, quando o nível da água abaixava, limpavam as moradias e colocavam as coisas de volta em seu devido lugar. Mas, daquela vez, sucedeu algo inusitado:

Aqui sempre teve enchente aqui, mas sempre para na praça. Essa enchente grande que deu, todo mundo começou a falar... a enchente chegou no mercado, a enchente já passou o mercado, está subindo na rua de cima... daí, quando era seis horas, o marido de uma funcionária daqui, ele avisou todo mundo, a enchente nunca chegou aqui em cima, mas está chegando, já está subindo... a enchente já está no velório e o velório é na esquina... fica nessa direção [...] daí, quando foi oito horas, um senhor chegou e ele disse: 'gente vamos sair. A água já entrou aqui e está numa altura que o doente não pode ir

16. Entrevistado A, Zona Rural, março de 2012, grifo nosso. 
andando, tem que ser carregado, já está quase no segundo degrau da escadaria da entrada' (informação verbal ${ }^{17}$ ).

A gente já estava acostumada com um metro e meio, dois metros, as coisas já estavam arrumadas pra dois metros né... a gente punha a geladeira em cima da cadeira, a gente pegava os cobertor, punha tudo em cima do guarda-roupa. Mas, dessa vez, não teve jeito, às duas da manhã a água já tinha coberto até a casa já (informação verbal ${ }^{18}$ ).

A gente jamais imaginava que ia chega aqui, nunca aconteceu, como diz, tudo nesse mundo tem a primeira vez, ninguém imaginava que ia entrar dentro de casa, o povo falava, duas horas abaixa era uma hora, quando era duas horas ninguém ficava aqui [...] não vai abaixar nada, a gente saiu com a roupa do corpo e os documentos, o resto (informação verbal ${ }^{19}$ ).

A gente mora aqui faz 32 anos, nunca aconteceu isso, nunca pegou água, pegava na rua ali embaixo, isso é o que tinha, só na rua, ninguém esperava, na cidade, nesse horário, pessoal do banco, cartório, ninguém esperava (informação verbal ${ }^{20}$ ).

A gente estava acostumada, a mais grande que deu nessa altura aqui, a gente nunca perdeu tudo, as coisas. Então, a gente erguia tudo que tinha, porque dava tempo. Ela vinha devagar, a gente já fica esperto, fazendo cavalete de pau, pondo as coisas em cima, não perdia. Mas, essa aí, foi pra arrasar mesmo (informação verbal ${ }^{21}$ ).

Essa enchente surpreendeu os munícipes de modo geral, como relatam os idosos. Misturaram-se as providências por buscar salvar alguma coisa nos estabelecimentos religiosos ou alguma coisa em casa, o impulso de ir ao encontro de familiares - para se proteger e protegê-los -, e a perplexidade diante do que acontecia na moradia e ao derredor. Se as enchentes recorrentes desorganizavam em alguma medida a vida cotidiana, essa era uma interrupção já esperada e calculada pelos moradores. Como, recorrentemente, a água chegava a dois metros de altura, os luizenses possuíam práticas preparativas para lidar com esses acontecimentos. Porém, a inundação ocorrida no ano de 2010 rompeu bruscamente com os cálculos feitos com base nas ocorrências dos anos anteriores. A água, dessa feita, chegou a quatorze metros acima do leito (regular) do rio e deixou a comunidade atônita:

Quando começou a encher aqui, eu me alarmei porque sempre tem. E começou a subir a água e entrar na minha casa, mas eu achei que a água ia subir, mas ia descer logo. $\mathrm{E}$ ela subindo... pra falar a verdade, acho que a gente ficou meio abobalhada e saímos. Eu saí só com a roupa do corpo, não levei nada mais do que meu próprio corpo, a calça preta e a blusa e saí, e saiu minha irmã, que fez agora 95 anos, e fomos pra casa da minha irmã mais pra cima que era um sobradinho, e

17. Entrevistada H, Centro, março de 2013, grifo nosso.

18. Entrevistado G, Várzea dos Passarinhos, março de 2013, grifo nosso.

19. Entrevistado B, Várzea dos Passarinhos, março de 2013, grifo nosso.

20. Entrevistado B, Várzea dos Passarinhos, março de 2013, grifo nosso.

21. Entrevistada J, Várzea dos Passarinhos, março de 2013, grifo nosso 
saímos de barco porque não aguentava o peso da água, e ficamos na casa dela (informação verbal ${ }^{22}$ ).

Quando eu saí, a água tava aqui em mim. Eu levei esses vasos meu, porque eu quero muito bem minha flor, e eu não tinha machucado a perna ainda. Eu não podia acudir minhas roupas, eu ia acudir meu vaso. Levei e pus ali, que não tinha aquela grade [...] aí deixei o vaso e fui pôr os mais pequenos lá [...] a água já estava passando os degraus. Daí, eu segurei aqui, que já tinha tirado a minha irmã, ela estava lá em cima, num barreiro que dava medo. Falei que ela não ia morrer, que ninguém ia morrer, porque eu estou acostumada, toda enchente que dá eu tô sozinha aqui, eu não tenho marido, né? (informação verbal ${ }^{23}$ ).

Cobriu tudo, pegou o sobrado todo da turma ali de baixo, o fórum, pegou metade do segundo andar, perdeu também, era um de janeiro, chamaram o pessoal e colocaram no segundo andar, tiraram tudo, depois de cinco dias com água parada. [...] Quando abaixou a água, tinha maca, tinha geladeira, tudo em cima das casa, os carro ficaram tudo em cima do outro, lá perto do mercado, uma geladeira ficou quinze dias em cima do telhado... (informação verbal24).

Subiu rápido mesmo e, quando a gente saía, não dava pra pegar nada. Ainda coloquei uma cama assim, e pus aquele guarda-roupa em cima de uma cama aqui; aí, enquanto eu fui lá na cabeça da ponte ver a água, eu não pude mais entrar aqui. [...] Eu voltava eu via tudo assim e não tinha como entrar na casa, nós descia e ele tava lá perto do cruzeiro, ali tem um cemitério e eu saí ali naquele poste que tem lá, olhava a água, aquele mar de água, e voltava pra lá, olhava pro alto da casa, dava medo e fiquei pra lá (informação verbal $\left.{ }^{25}\right)$.

A perda da casa, por danificação ou destruição, e de pertences pessoais que ali eram guardados e utilizados, é outro aspecto da particularidade do desastre. Com o imóvel avariado, muitas famílias ficaram subitamente privadas de seus móveis, eletrodomésticos, itens de vestuário, utensílios domésticos, entre outros, muitos dos quais não tinham formas de recuperação e reutilização. Esvaziaram-se, desse modo, para algumas famílias, as possibilidades imediatas de retomada das rotinas de antes; mas, para outras, houve perda mais duradoura da qualidade de vida.

Além do sofrimento pela perda das coisas que constituiam meios de viabilização da rotina na vida privada e que, também, tinham importância no universo simbólico, havia a lembrança dolorosa dos momentos em que os perigos pairavam e exigiam das famílias esforços urgentes e extraordinários, em muitos casos vãos. Na luta contra o tempo, para acudir as coisas, muitas famílias saíram vencidas. A perda das coisas, incluindo a dos meios de trabalho, somada à presença não usual de forças militares e ao surgimento de novas ameaças, como a de saques do que sobrou, foi objeto de preocupações com a perda do rumo original das vidas pessoal e coletiva, tal como eram con-

22. Entrevistada P, Centro, março de 2013, grifo nosso.

23. Entrevistada J, Várzea dos Passarinhos, março de 2013, grifo nosso.

24. Entrevistado B, Várzea dos Passarinhos, março de 2013, grifo nosso.

25. Entrevistado H, Benfica, grifo nosso. 
duzidas até então. No caso dos munícipes que ficaram à espera de resgate, confinados em suas casas em virtude das águas que subiram rapidamente, não foram as equipes técnicas de socorro quem lhes salvaram a vida, mas as equipes locais de rafting que, posteriormente, ficaram reconhecidas comunitariamente como "Anjos do Rafting". Isso refez radicalmente os sentidos comunitariamente atribuídos a essa prática de esporte e lazer, bem como os vínculos dos seus praticantes com a comunidade, posto que, antes do desastre, essas equipes de esportistas eram vistas como "uma turma de desocupados" e "vagabundos". Devido tanto às estratégias específicas que essas equipes tinham para lidar com os trechos turbulentos dos rios da região quanto ao conhecimento prévio acerca do traçado da cidade, a imediata missão de resgate à qual se lançaram voluntariamente evitou que houvesse mortes nessa enchente:

Começou vir a água por debaixo da porta e, aí, foi todo mundo desesperando, começamos a sacar remédios, sacando, levava pra cima, uma meia dúzia de gente, um correcorre, sobe escada e leva pra cima, acudindo o que tinha mais valor [...] já tinha caído um pedaço da torre da igreja, aqui estava que nem o mar [...] aí, chegou um barco pra tirar a gente ali e já encontrou com nós na escada e era um corre-corre, gente saindo, criança [...] Quando nós subimos no barco a água já estava subindo a escada, aqui já estava completo de água. (informação verbal ${ }^{26}$ ).
Acabou tudo, loja, não tinha onde comprar nada pra comer, se precisasse trocar uma peça não tinha, nem pra comprar um sapato, não tinha nada (informação verbal27).

Parecia o Vietnã, muita polícia, aqui de trás até aqui embaixo na saída da pista, tava 24 horas por dia o exército, porque dá muito roubo, tinha gente que já aproveita pra pegar. Tá sujo, mas pode ficar tranquilo, onde está. Vinte e quatro horas, três turmas, das seis da tarde à meia noite, a turma do exército trabalhava. Ia 10 , voltava 10 pra rua vigiar. [...] 0 botijão, que foi a única coisa que sobrou roubaram muito, bicicleta e outras coisas que a água não chegou a levar muito. Enfia ali, leva lá, numa viela no morro, tinha uma vila ali no morro, e lá pra ver de cima. Entregava o pessoal e levava lá, na outra vila, uns de lá vinha pra cá, os de cá ia pra lá, atravessava a enchente (informação verbal ${ }^{28}$ ).

Alguns dias após a enchente, a cidade permanecera sem mantimentos, sem eletricidade. A lama e os destroços das casas invadiam a rua, modificando completamente a configuração do espaço público. Quando as águas baixaram, novos desafios se impuseram para os luizenses: descartar os objetos que ficaram imprestáveis, mas sem que o serviço de coleta fosse adequado; conviver com o mau odor impregnado na casa, mas, na tarefa de limpeza da moradia, ficar sem água para a higienização e sem condições de substituir os bens perdidos; dentre outros. É o que ilustram os relatos a seguir:

26. Entrevistado L, Centro, julho de 2012, grifo nosso.

27. Entrevistado B, Várzea dos Passarinhos, março de 2013, grifo nosso.

28. Entrevistada C, Várzea dos Passarinhos, março de 2013, grifo nosso. 
Tinha até peixinho do rio aqui dentro, a gente achou tudo, tinha de tudo. [...] E o mau cheiro, minha filha! Jogava tudo o que era coisa e não sai. Ficou mais de ano você sentia o cheiro horrivel da lama. Jogava água na parede, lavava o chão, lavava tudo (informação verbal ${ }^{29}$ ).

0 povo jogando as coisas pra rua, deixou pelada a casa (informação verbal ${ }^{30}$ ).

Meus irmãos foram limpar a casa, mas a casa estava super suja, não dava pra gente morar lá ainda, sem móveis, dormir no chão, sem água, porque demorou pra voltar a água [...] oito dias depois que a gente tinha entrado na casa, meu filho subiu no telhado, telha Brasilit, e ele tirou um monte de areia. Não tinha como ficar com aquela areia lá. 0 vento vinha e sujava todas as coisas. Sujava até os alimentos se a gente abusasse, o vento jogava tudo (informação verbal ${ }^{31}$ ).

A gente perdeu muito... parava um caminhão basculante ali e a gente ia jogando as coisa fora, e ele ia levando embora, jogava um negócio que você nem sabia o que era, era um monte de lodo, foram dois meses pra lavar esses dois cômodos aqui, eu consegui ficar dentro da casa depois de uns quatro dias que baixou. E nós começamos a limpar, depois disseram que vinha a luz, e veio mesmo mais tarde (informação verbal ${ }^{32}$ ).

Houve quem, no pico da enchente, só saísse de casa com a roupa do corpo e acreditasse que o reaproveitamento dos bens danificados era impossível: “a água foi subindo... nós fomos acompanhando. As coisas, perdemos tudo. Só não perdemos a vida" (Entrevistado E, São Benedito, grifo nosso). E há relatos similares, os quais enfatizaram a preocupação dos afetados com os seus pertences considerados insubstituíveis - seja pela necessidade de natureza econômica, por suas preferências e hábitos ou por aquilo que o bem representava em suas memórias acerca de importantes acontecimentos em sua trajetória de vida:

Não peguei nada, nem o chapéu eu não peguei, perdi tudo, só fiquei com a roupa do corpo. Ali na farmácia perdeu tudo, ali na padaria perdeu tudo [...] ficamos no prejuizo, estamos devendo até hoje, tem prejuízo até hoje, dividas pra pagar (informação verbal ${ }^{33}$ ).

Não salvou nem um paninho de prato, quanto mais o resto! Aqui colocamos uma tábua, foi pro chão, pro ralo, eu joguei, você pegava uma coisa aqui, a água aqui, você virava pra pegar outra, a água já tava aqui, foi subindo muito rápido. [...] Estava todo mundo aqui, mas não adiantava nada, sair pra onde? Carregar pra onde? Não tinha. 0 lixo tava até o rio, Santo Deus [...] Só sentindo na pele pra saber, a gente vê na televisão. Agora a gente vê e dá dó. Ainda se fosse água limpa, tudo bem, mas água grossa, imunda, cheia de bicho, perde tudo. Como era véspera de Ano Novo, as casas estavam lotadas de carne [...] aquele mau cheiro, Santo Deus! Teve gente que foi aproveitar geladeira, mas deixaram um frango dentro da geladeira novinha. Pre-

29. Entrevistado B, Várzea dos Passarinhos, março de 2013, grifo nosso.

30. Entrevistado C, Várzea dos Passarinhos, março de 2013, grifo nosso.

31. Entrevistado F, São Benedito, março de 2013, grifo nosso.

32. Entrevistado L, Centro, julho de 2012, grifo nosso.

33. Entrevistado L, Centro, julho de 2012, grifo nosso. 
cisou jogar fora, que não saía o mau cheiro. E depois no ano novo, todo mundo sem ter nada pra comer, porque foi sexta-feira [...]. Ali tem um vizinho que conta: o que ele queria era comer pururuca, sabe o que é pururuca? Ele fez e foi enchendo e ele já tava esperto. Fez o pratão de pururuca pôs no forno e ia esquentar de tarde. Começou a encher, ficou apavorado, e colocou [o prato] em cima do forro. Foi a pururuca dele pro beleléu. Foi todo mundo falando que tinha feito um bolo gostoso, e falava 'deixa pra comer amanhã'. Aqui em casa tinha as gelatinas coloridas. Ai que vontade de comer a gelatina, a geladeira tava longe. 0 pior é que não abriu, ficou dentro da geladeira, teve que joga tudo fora... (informação verbal ${ }^{34}$ ).

A roupa nunca é a mesma, perde a roupa, rodou. Uma blusinha assim é legal, uma camisa que eu tinha e uma calça preta, e você compra não é aquilo também. Eu lembro da calça preta até hoje, um sapato, essas coisas marca, você gosta de uma roupa, de um sapato. [...] Aqui, tinha parente do meu sobrinho, peguei calça, camisa e cueca dele. A minha mulher não queria, ela falava 'eu não visto essa calcinha achada na rua'. Como ela tava acostumada com aquele ceroulão, e não tinha. A calça, camisa, cueca, tudo usado, peguei a roupa dele. Até eu ganhei umas calças de um amigo que mora em Natividade. Depois fui na pechincha que tinha um monte de roupa pra escolher. Até normalizar, tinha dona de loja vestindo roupa daquele montão (informação verbal ${ }^{35}$ ).
Aqui tinha uma estante grandona, daquela colonial. Virou aqui. Na cozinha, tinha um armário de parede que eu não sei de que jeito o armário boiou e virou com a boca pra cima, e as coisas sumiu tudo e não tinha nada dentro dele. E tinha compra, vasilha na parte de cima... tinha tudo e sumiu tudo, e tudo no chão com a bagunça. E no quarto arrastou tudo e eu não podia entrar no quarto, acabou tudo e eu deixei a janela aberta, que eu tenho medo de fechar a casa e cair. Daí, as coisas foram tudo embora, o vitrô eu esqueci aberto, mas perdi as coisas. Mas, se deixar aberto, ia ficar tudo fedendo e não ia adiantar de nada. Mas rodou tudo, foi parar edredom meu no quintal da vizinha, ela lavou, sorte que alguém aproveitou. Mas, a gente mesmo, perdeu tudo (informação verbal ${ }^{36}$ ).

Tinha água em cima da minha casa, e meu sobrinho disse: 'tia, eu passei em cima da sua casa, pus a mão no telhado e do telhado da vizinha, e minha casa estava com um metro em cima do telhado de água'. Pesou a água, pesou a telha, e desceu, com as paredes e tudo porque era pau a pique, e desceu em cima do meu presépio, do meu guarda roupa [...]. A defesa civil não deixou entrar porque caiu tudo, ficou 21 dias sem mexer. Daí acabou de apodrecer. [...] Foi triste, sem roupa, meus vestidos de festa foi tudo embora, meus sapatos bonitos foram embora. Só na saudade agora (informação verbal ${ }^{37}$ ).

Meus irmãos tentaram subir com as coisas pra cima, mas teve uma hora que não deu

34. Entrevistada C, Várzea dos Passarinhos, março de 2013, grifo nosso.

35. Entrevistado B, Várzea dos Passarinhos, março de 2013, grifo nosso.

36. Entrevistada J, Várzea dos Passarinhos, março de 2013, grifo nosso.

37. Entrevistada P, Centro, março de 2013. 
mais, a água cobriu tudo. Foi muito rápido! A gente ficou meio desolado, pois a gente ficou num trecho que você não podia ir nem pra frente e nem pra trás. Pra frente tinha água e pra trás tinha um barranco que estava caindo. Então o que deu pra salvar salvou, mas o resto a água levou tudo embora (informação verbal ${ }^{38}$ ).

Os relatos dos idosos entrevistados indicaram haver uma sensação difusa de desfiliação social decorrente do desastre, fosse em razão da perda, irreparável ou circunstancial, de sua territorialidade mais substantiva - a casa -, fosse em decorrência das perdas de bens de valor simbólico e sentimental de grande monta nela contidos. A falta de acesso à casa e às suas respectivas funcionalidades colocou muitos moradores locais, inclusive os idosos, na condição de desalojados ou desabrigados. Impuseramse a eles não somente intranquilidades quanto ao futuro, mas também um crítico ajustamento aos desafiadores limites para realizar as suas rotinas da vida cotidiana, em patamares bem inferiores às suas antigas rotinas. Predominou, em alguns casos, certa acomodação aos patamares limitados de atendimento recebido na casa de parentes e amigos bem como em abrigo público; em outros casos, houve a busca por alternativas, as quais também apresentaram alguma precariedade. Os relatos acerca desses deslocamentos involuntários foram aqueles em que as palavras tiveram mais dificuldades em serem proferidas e compartilhadas durante a entrevista. Os entrevistados abordados ficaram mais circunspectos nesse tema; as feições denotavam as emoções mais intensas e de difícil contenção, certo incômodo entre aquilo que era solicitado a ser lembrado e o desejo de esquecê-lo. Muitas vezes, um longo silêncio preenchia a interação.

A comida [no abrigo] não era assim aquela comida, mas tudo bem. Pra quem tava sem nada, tava ótimo (informação verbal ${ }^{39}$ ).

E ficamos ali [no abrigo], 18 pessoas, não tinha mais nada pra comprar, tudo fechado, não tinha água. [...] Pra eu poder vestir uma roupa, já estava na pousada, fazia três dias que eu estava com a mesma roupa, a roupa que eu saí, molhado, abri trouxas que vieram de Taubaté, encontrei uma roupa pra mim e pra minha irmã, e trocamos de roupa e escovamos o dente, que a sobrinha levou escova. Daí, começou a chegar ajuda... [...] os três primeiros dias foram tristes... Aí, pra dá descarga na privada, a gente escovava dente dentro e cuspia numa vasilha, todo mundo tinha que fazer aqui pra jogar na privada [...] chegamos lá [no abrigo], um tormento, criança, famílias, cachorro latindo, uma trapalhada lá. E minha irmã falou, não vamos ficar aqui. Daí, fomos lá pra cima do meio do pasto, que tinha uma casinha. Chegamos lá, não tinha nem uma cadeira pra sentar, aí meu irmão começou a ficar nervoso, e saímos, e voltamos pra casa do meu irmão (informação verbal ${ }^{40}$ ).

São de destacar, ainda, situações em que a intensa desfiliação social que se processava desde antes do desastre não tornava esse acontecimento especialmente dramático na tessitura de uma vida já materialmente esgarçada.

38. Entrevistada F, São Benedito, março de 2013.

39. Entrevistada C, Várzea dos Passarinhos, março de 2013, grifo nosso.

40. Entrevistada P, Centro, março de 2013, grifo nosso. 
0 pessoal sentiu muito, mas eu não esquentei muito com essas coisas. Mas, a turma aí sentiu bastante. 0 pessoal que tem mais, sentiu mais, sabe como é que é, né? [...] A vizinha, com as coisarada que ela tinha dentro de casa, sentiu mais. A enchente levou tudo, o que a enchente não levou, ficou lá pra cima. Agora, eu já não senti muito porque eu não tenho muita coisa pra perder. Sabe como é que é? Eu já não tinha muita coisa pra senti falta (informação verbal ${ }^{4}{ }^{1}$ ).

Dentre as perdas imateriais, irrecuperáveis, podemos destacar as fotos de família que contextualizavam ocasiões especiais e entes queridos já falecidos. Eram objetos importantes para referenciar os vínculos emocionais, a identidade do sujeito e sua trajetória de vida:

As fotos... tinha foto do meu pai, dos irmãos. Então acabou tudo, pegou água, daí perde muita coisa, você fica sozinha, fica indigente, você fala tal fulano é da minha família, ninguém sabe que era que as fotos foram embora, tinha um filho que faleceu, tadinho que as fotos foram tudo embora, [...] foto de família, pra arruma outra, onde? Como? Se a pessoa já morreu? (informação verbal $^{42}$ ).

Isso é o que a gente mais sente, a foto do meu pai que eu tinha uma relíquia da gente, porque a gente, tinha foto da minha mãe, hoje não tem mais. Isso eu senti muito perder porque nunca mais eu vou ter, fiquei sem minha mãe por dois anos, daí, meu tio deu uma foto dela pra mim. Foi um grande presente, era a relíquia que eu tinha e rodou tudo (informação verbal ${ }^{43}$ ).

As fotos, inclusive, tinha de dois filhos que faleceram. Eu tinha num pacote, perdi tudo, dos meus avós, dos meu pais, perdi tudo, do passado não tem mais nada guardado, eu tinha tudo (informação verbal ${ }^{44}$ ).

Minhas fotos... Devia ter umas 3,5 mil fotos. Toda a minha história, de criança, o teatro, procissão, perdeu tudo, foi tudo embora, a chuva levou tudo (informação verbal ${ }^{45}$ ).

Uma das entrevistadas mencionou que, na perda de todas as suas fotos, havia as de seu filho já falecido. Essa teria sido a única lembrança material dessa relação maternal. A voz embargada da idosa mostrava o quanto aquela experiência dupla de perda, do filho em si e do seu registro visual, lhe causava um intenso sofrimento. A fotografia é uma imagem de algo que se situa no passado, mas que, ao ser guardada com cuidado para ser contemplada amiúde, também traduz aquilo que se deseja reviver, sobretudo em termos da evocação dos afetos em relação aos que ali são reproduzidos. A perda da fotografia obstaculiza essa prática de rememoração.

Outro elemento essencial que foi destacado como perda imaterial foram os santos. Uma senhora que reside no bairro da Várzea dos Passarinhos relata que a única coisa que tirou da casa no momento da enchente foi uma imagem do Divino, que

41. Entrevistada D, Várzea dos Passarinhos, março de 2013, grifo nosso.

42. Entrevistado B, Várzea dos Passarinhos, grifo nosso.

43. Entrevistada J, Várzea dos Passarinhos, março de 2013, grifo nosso.

44. Entrevistada 0, Ver de Perto, março de 2013, grifo nosso.

45. Entrevistada P, Centro, Março de 2013, grifo nosso. 
ela tinha na sala de sua casa. No processo de limpeza de sua casa, conseguiu resgatar todos os santos que tinha. Assim como ela, vários moradores destacaram a importância de encontrar os santos:

Você acredita que Nossa Senhora Aparecida é tão milagrosa, que ela não tombou no meio do lodo, do jeitinho que ela ficou de pé encheu de lodo e não saiu do lugar, os outros santos caíram, achei pela casa, e ela, não (informação verbal ${ }^{46}$ ).

0 que eu sinto era o altarzinho que eu tinha do Santo. [...] Meu filho achou uma imagem de Nossa Senhora no barro, e ele levou pro Padre pra ver se não era da Igreja, daí o padre guardou. [...] depois as pessoas vão lembrando das coisas que perdeu e acha muita falta, mas fazer o quê? Não volta mais. (informação verbal ${ }^{47}$ ).

Meu presépio era grande, como daqui lá, a parede caiu em cima, e milagrosamente eu encontrei o menino Jesus da minha mãe no meu pé, depois de quase um mês, daí peguei, lavei bem ele. [...] a Nossa Senhora de Fátima, ela tinha um manto, quase igual o da Nossa Senhora Aparecida, e ela estava no quarto na minha irmã em cima de uma cômoda, milagrosamente encontraram na mesa da outra sala, a água trouxe a imagem e colocou lá, o manto foi embora, mas ela ficou. Está lá em casa (informação verbal ${ }^{48}$ ).

Por fim, as lembranças do desastre vivenciado em São Luiz do Paraitinga se re- fletiam no conteúdo dos sonhos que alguns dos idosos entrevistados passaram a ter desde então. Tais sonhos foram como que indícios da perenidade da memória em torno dessa experiência, pessoal e coletiva, de insegurança e de desamparo, mesmo após a água e a lama terem baixado:

Eu sonho, uma vez por semana, às vezes seguida, que a enchente vem vindo, e eu tô dentro dela, às vezes é água suja, às vezes é água preta... [...] Sonho, sonho, e eu tive um sonho antes da igreja, que eu saí daqui da capela encontrei com água nesse pedaço de rua, depois aconteceu [...] Eu sonho sempre, às vezes 2 ou 3 vezes por semana, a água vem vindo e eu tô nela, eu não posso entrar na cidade que a ponte tá cheia de água (informação verbal ${ }^{49}$ ).

Eu não durmo de noite, eu sonho que eu tô caindo na água [...] que a água está me pegando na cama, que eu tô caindo no meio da água (informação verbal ${ }^{50}$ ).

As enchentes do sonho não são como as do passado, em que as estratégias costumeiramente utilizadas davam conta de minimizar as perdas. 0 sonho traz, ao contrário, as enchentes bruscas que evocam o sentimento de desespero conhecido desde o ano de 2010. 0 sonho consiste na expressão íntima do ser, mas também, como ressalta Martins (2000, p. 69), “a gestação do conceito de sonho se determina pela mediação das experiências sociais concretas do vivido". Para o referido autor, a casa

46. Entrevistada J, Várzea dos Passarinhos.

47. Entrevistada F, São Benedito, março de 2013.

48. Entrevistada P, Centro, Março de 2013.

49. Entrevistada P, Centro, março de 2013, grifo nosso.

50. Entrevistada J, Várzea dos Passarinhos, março de 2013, grifo nosso. 
aparece no sonho "como cenário de uma vida rotineira ameaçada - pelos temores oriundos diretamente da vida cotidiana (a vida cotidiana como sociabilidade, tempo e realidade da ameaça e do medo) [...] pela suspeita, pela incerteza" (MARTINS, 2000, p. 81). Não por acaso, o sonho perturbador bem como a insônia se confundem com uma rotina ainda intranquila, na qual afloram inquietações pessoais de inúmeras ordens, mas que, na vida coletiva, também se mostram como intranquilidades comunitárias, como o receio de que a vida cotidiana, novamente, fique por um triz:

Foi muito feio, terrível, só pra quem passou. [...] Tem dia que eu choro aqui, de medo de acontecer comigo aqui o que tá acontecendo lá [noutro desastre]. Nosso fim vai ser acabar daquele jeito? Quando o rio enche, eu já fico com medo, mas acho que não dá mais, né? [...] todo ano que passa, vai chegando novembro, dezembro, a gente já vai ficando perturbada. Eu fico mesmo, perco o sono, a água já chegou no bequinho esse ano [...] Quando enche o rio, já fica aquele zumbido na minha cabeça, a turma já fica gritando na rua, porque ninguém dorme de medo e a gente também não dorme, fica todo mundo pra rua olhando o rio. Não tem perigo, mas faz isso (informação verbal51 ${ }^{51}$.

Ademais, Martins (2000) atenta para a questão de que os sonhos nos aterrorizam na medida em que denunciam o que fazemos ante os nossos temores e terrores e que, embora pareçam algo muito íntimo, refletem a cultura do grupo ao qual pertencemos.

\section{Considerações Finais}

A construção paulatina de uma memória comum de idosos sobre um desastre tem como ponto de partida, ainda que por vezes não explícito, uma ideia reelaborada do passado recente, pois é lá que estão referenciados os sistemas de objetos relevantes e de práticas rotineiras da vida privada e pública que, por terem sofrido uma grave perturbação na realidade presente, justificam a forma penosa como a precariedade circunstancial é experimentada e narrada. Refaz-se, assim, a articulação entre o passado e o presente através das restrições de possibilidades que um desastre evoca. Embora haja sentimentos envolvidos nessa narrativa e a subjetividade esteja em jogo, essa construção é perpassada pela dinâmica social na qual os sujeitos estiveram envolvidos e atuaram, de modo que suas memórias pessoais não se desconectam dos fatos sociais dos quais participaram, forjando, assim, uma memória comum.

0 desastre de São Luís do Paraitinga foi revisitado por meio da memória oficial e das memórias comuns e, por intermédio de ambos, apresentou-se como um acontecimento socioambiental complexo e sujeito a múltiplas interpretações. 0 meio técnico tende a concebê-lo como uma perturbação numa localidade - a qual se expressa por perdas e danos, essencialmente quantificáveis, e por uma visão estanque da destruição havida -, enquanto o meio social local tende a colocar o foco em aspectos qualitativos de seu envolvimento na cena, destacadamente no processo como essas perdas 
se deram e nas formas de atuação para evitá-las ou para adaptar-se às circunstâncias.

Tivemos o intuito de apresentar alguns elementos para a reflexão sociológica em torno da importância da memória pessoal de idosos para compreender a trama social envolvida num desastre - sua memória comum de sofrimento social -, através do tecido de suas singularidades que não é visível pelos documentos oficiais. Trazer à tona aspectos das memórias comuns dos idosos acerca de como vivenciaram o referido desastre permite indicar-lhes que suas preocupações e experiências de sofrimento não apenas lhes pertencem, em termos pessoais, mas também se entremeiam e anunciam a sua não conciliação - e mesmo alienação - em relação à versão oficial. Nesse entremear, a arquitetura do desamparo social se torna mais nítida e, portanto, dá sinais de que as políticas técnicas de resposta aos desastres têm um longo caminho a percorrer na garantia dos direitos de cidadania.

A memória comum que permeia os relatos pessoais dos idosos, relacionada a esse caso como também a outros acontecimentos que marcam a trajetória coletiva luizense, está em contínua construção e reelaboração, de modo que novos elementos intervenientes, trazidos tanto do passado quanto do presente, podem alterá-la a qualquer momento. Tal metamorfose é o que indica que o mundo simbólico, pessoal e coletivo, é pulsante e precisa sê-lo, principalmente quando está sob um acontecimento trágico e inesperado, que apresenta circunstâncias adversas e fora de controle.

Há que se observar que uma comunidade local não está isenta do risco de estereotipia do desastre, influenciada pelo discurso oficial, sobretudo, em razão da imposição da racionalidade militarizada que permeia a formação do quadro humano de defesa civil, e das técnicas e interpretações que seus agentes utilizam e disseminam no cenário de devastação no qual adentram. Essa estereotipia, quando ocorre, realiza um exercício mistificado de invulnerabilidade, resultante da proibição velada de explicitação do medo de quem sofre naquelas circunstâncias (DEJOURS, 2006), pela qual o sujeito é impedido de vocalizar o processo de desamparo no qual está imerso. Se no relato dos idosos de São Luiz do Paraitinga tivesse havido uma reprodução automática da concepção oficial do desastre, os riscos de estereotipa teriam sidos confirmados. Mas, ao contrário disso, os relatos fazem surgir os indícios de uma memória alternativa. Nela aparece, com muitas tonalidades, a extensão do sofrimento social correspondente à limitação das providências públicas para garantir a proteção de direitos e, ainda, aparece a resistência comunitária para manter o domínio da palavra própria sobre os acontecimentos do lugar.

Nas ferramentas oficiais de interpretação do desastre, tem preponderado uma descrição do espaço afetado, cuja abordagem é predominantemente quantitativa, setorizada e estanque, com foco privilegiado em certos aspectos físicos componentes da vida social e econômica local, tais como o número de pessoas afetadas, de moradias destruídas, de estabelecimentos comerciais destruídos, de quilômetros de vias danificadas, de toneladas de grãos perdidos e assim por diante. Por seu turno, as memórias pessoais convergem num esforço de busca de nitidez de aspectos qualitativos de perdas e danos. Nelas, prepondera como traço comum um empenho narrativo de articulação de aspectos físicos mais detalhados do ambiente privado ou comunitário com as relações sociais ali travadas ou deles dependentes, além de fornecerem um re- 
pertório relevante de significação socioambiental dinâmica do lugar. Nas estranhezas e nos desencontros que persistem entre a racionalidade institucional macrossocial, na qual o desastre é uma abstração que padroniza as representações do meio técnico, e o universo microssocial, em que o desastre é efetivamente vivido, há sinalizações do porquê de esse tipo de crise aparecer e se tornar crônica. A face humana do desastre - sem a qual não haveria, por definição, desastre algum -, como que desaparece das palavras que alicerçam as providências técnicas. Esse desaparecimento desenodoa o lugar, o descomplexifica, numa dilaceração que culmina num processo de desumanização. Em vista disso, as lembranças de idosos acerca de um desastre que vivenciaram poderiam, eventualmente, ser consideradas como um processo pessoal e social potente, capaz de ressituar os acontecimentos e reumanizar sua passagem por eles.

De um ponto de vista sociológico, a prática de indissociabilidade dos atributos sociais palpáveis e invisíveis de um desastre, presente nos relatos de idosos, os torna mais ricos, interessantes e verossímeis para explicar a natureza desse acontecimento do que as informações contidas na documentação ofıcial. A larga participação do referido sujeito no processo de construção, privado e público, daquilo que se tornaria escombro diante dos seus olhos, é um aspecto a considerar nessa riqueza interpretativa que o meio técnico não captura com seus instrumentos atuais. A tessitura da vida cotidiana - e, portanto, da vida aparentemente banal -, é evocada com grande peso nos relatos colhidos, suscitando um enquadramento alternativo daquilo que poderia ser compreendido como um desastre. Nessa concepção alternativa, os acontecimentos que envolvem a degradação simultânea da pessoa, da comunidade e do ambiente são revelados de uma maneira mais integrada e de modo a destacar a natureza simultaneamente material e simbólica, como também objetiva e intersubjetiva do sofrimento vivenciado. E, ainda, os relatos contêm uma narrativa passível de abranger as estratégias pessoais e coletivas de resistência adotadas naquelas circunstâncias, o que passa ao largo dos documentos oficiais sobre desastres.

Por fım, mas não menos importante, a associação entre o relevo de serras e encostas íngremes e as chuvas concentradas, que são características do período de verão na região Centro-Sul do país, constituem fatores que suscetibilizam muitas cidades na referida região (MENDONÇA, 2010), e São Luiz do Paraitinga se insere nesse contexto, o que aponta para uma possibilidade de que desafios similares se repitam. Dentre eles, destacamos: o de proteção da configuração territorial do lugar, isto é, os elementos físicos, arquitetônicos e paisagísticos que emolduram as rotinas de interação social nas vidas privada e pública; o de aperfeiçoamento das ações técnicas e comunitárias de resposta (resgate e reabilitação) num desastre; o de proteção preventiva dos bens de valor material e simbólico que garantam a reprodução social e a afırmação identitária da pessoa, da família e da comunidade; o de provimento da plena recuperação dos moradores que porventura sofram um novo ciclo de perdas e danos; e assim por diante. Tudo indica que esses desafios a serem enfrentados imporão uma nova concepção de lugar aos luizenses e, com ela, novos elementos para a recomposição dinâmica da memória social local.

Como refletiu Martins (2000), a vida cotidiana exige assentar-se num chão próprio e num tempo social específico para se desenvolver, seja no referente às rotinas da 
pessoa como da coletividade a que pertence. Assim, se porventura esse chão sofre distúrbios imprevistos, os sujeitos envolvidos requerem que o tempo sofra os ajustes necessários, requerimento este que se dá à custa de padecimentos e dificuldades de várias ordens que as ideias dominantes não captam e pelos quais não têm interesse. É nesse sentido que a memória comum de idosos afetados no desastre tende a ser vista, pelo meio técnico, como uma versão marginal e desqualificada sobre os acontecimentos. Contudo, essa versão, a do desastre vivido, carrega consigo a força de uma significação da experiência, pessoal e coletiva, de estar no centro do acontecimento trágico e, portanto, supera o silêncio para se manifestar como um locus concreto e simbólico de sofrimento social que define aquilo mesmo que o senso comum considera que seja um desastre. Também advertiu o referido autor que a memória não é apenas uma lembrança verbalizada, mas algo que se mescla a outros elementos, como "nos gestos, nos gostos, na audição, nos sotaques, no paladar, no olfato, nos cheiros" (MARTINS, 2000, p. 146), o que, no caso luizense, tem muito a dizer sobre um modo singularmente caipira de viver e de sofrer, que este texto - pela necessidade de síntese, e por estar condicionado ao universo das palavras e dedicado a um certo foco do problema - não teve condições de exprimir, mas que fica aqui como um desafio para estudos sociológicos futuros.

\section{Referências}

BOSI, A. Literatura e resistência. São Paulo: Companhia das Letras, 2002.

BOSI, E. Memória e sociedade: lembranças de velhos. São Paulo: T. A. Queiroz, 1979.
BOURDIEU, P. 0 poder simbólico. 12. ed. Tradução: Fernando Tomaz. Rio de Janeiro: Bertrand Brasil, 2009.

BRASIL. Lei $\mathrm{n}^{\circ} 10.741$, de $1^{\circ}$ de outubro de 2003. Estatuto do Idoso. 1. ed. Brasília: Ministério da Saúde, 2003.

BRASIL. Ministério da Integração Nacional. Secretaria Nacional de Defesa Civil. Política Nacional de Defesa Civil. Brasília: Secretaria Nacional de Defesa Civil, 2000.

BRASIL. Lei $\mathrm{n}^{\circ} 12.608$, de 10 de abril de 2012. Política Nacional de Proteção e Defesa Civil (PNPDEC). Disponível em: <http:// www.planalto.gov.br/ccivil_03/_Ato20112014/2012/Lei/L12608.htm>. Acesso em: 01 jun. 2013.

CAMPOS, J. T. A imperial São Luiz do Paraitinga: história, educação e cultura. Taubaté: Resolução Gráfica, 2011.

CLAVAL, P. La géographie humaine face à la culture. Aurora geography journal, v. 0, p. 9-28, août 2006.

DAS V. Critical Events: an antropological perspective on contemporary India. New Delhi: Oxford University Press, 1995.

DAS, V.; P0OLE, D. El estado y sus márgenes: etnografias comparadas. Cuadernos de Antropologia Social, n. 27, p. 19-52, 2008.

DEJOURS, C. A banalização da injustiça social. Rio de Janeiro: FGV, 2006.

EYRE, A. Remembering: Community Commemoration After Disaster. In: RODRÍGUEZ, H.; QUARANTELI, E. L.; DYNES, R. R. (Orgs.) Handbook of disaster research. New York: Springer, 2007. p. 441-455.

FRIEDSAM, H. J. Reactions of Older Persons to Disasters caused Losses: A Hyphothesis on relative Deprivation. Gerontologist, p. 34-37, 1961. 
GIBSON, M. J. We can do Better: lessons learned for protecting older persons in disasters. Washington: American Association for Retired Persons, 2006. Disponivel em: <http://assets.aarp.org/rgcenter/il/better. pdf>. Acesso em: 01 fev. 2012.

HELLER, A. 0 cotidiano e a história. São Paulo: Paz e Terra, 2008.

INSTITUTO BRASILEIRO DE GEOGRAFIA E ESTATÍSTICA. Censo Demográfico 2010: Características da população e dos domicílios - resultados do universo. São Paulo, 2011. Disponível em: <http://www.ibge. gov.br/home/estatistica/populacao/censo2010/caracteristicas_da_populacao/resultados_do_universo.pdf>. Acesso em: 01 out. 2012.

MARCHEZINI, V. Processos de recuperação em desastres: discursos e práticas. São Carlos: RiMa Editora, 2015.

MARTINS, J. S. O senso comum e a vida cotidiana. Tempo Social: Rev. Sociol. USP, São Paulo, v. 10, n. 1, p. 1-8, maio 1998.

A sociabilidade do homem simples: cotidiano e história na modernidade anômala. São Paulo: Hucitec, 2000.

Sociologia da fotografia e da imagem. 1. ed. São Paulo: Contexto, 2008.

MENDONÇA, M. A vulnerabilidade da urbanização do centro-sul do Brasil frente à variabilidade climática. Investig. Geograf., Santiago, n. 42, p. 57-84, 2010.

NGO, E. When disasters and age collide: reviewing vulnerability of the elderly, $\mathrm{Na}$ tural Hazards Review, 2001. p. 80-89, May 2001.

ORIOLL, W. Psychosocial Issues for Older Adults in Disasters. DHHS Publication No. ESDRB SMA 99-3323. Washington: Center for Mental Health Services, Substance Abuse and Mental Health Services Administration, U.S. Department of Health and Human Services, 1999.

POULSHOCK, S. W.; CHEN, E. S. The Eldery in Aftermath of a Disaster. The Gerontologist. v. 15, n. 4, p. 357-361, 1975. Disponivel em: https://training.fema.gov/ hiedu/.../gerontology\%20and\%20em.do

WHITTINGTON, F. J. A timely recovery for literature on disasters and older adults. The Gerontologist, v. 51, n. 1, p. 132-137, 2010.

PERRY, R. What is a disaster? In: RODRIGUEZ, H.; QUARANTELLI, E. L.; DYNES, R. R. (Eds.). Handbook of Disaster Research. New York: Springer, 2007.

POLLAK, M. Memória, esquecimento, silêncio. Estudos Históricos. v. 2, n. 3, Rio de Janeiro, p. 3-15, 1989.

PROGRAMA DAS NAÇÕES UNIDAS PARA O DESENVOLVIMENTO. Atlas do desenvolvimento humano no Brasil. 2013. Disponivel em: <http://www.atlasbrasil.org. br/2013/perfil/>. Acesso em: 01 nov. 2013.

QUARANTELLI, E. L. A social science research agenda for the disasters of the $21^{\text {st }}$ century: theoretical, methodological and empirical issues and their professional implementation. In: PERRY, R. W.; QUARANTELLI E. L. (Orgs). What is a Disaster? New Answers to Old Questions. Newark: International Research Committee on Disasters, 2005. p. 325-396.

Epilogue. In: (Org.). What is a Disaster? Perspectives on the question. New York: Routledge, 1998. p. 234-273.

SÁ, C. P. Sobre o campo de estudo da memória social: uma perspectiva psicossocial. Psicologia: Reflexão e Crítica, v. 20, n. 2, p. 290-295, 2007. 
SANTOS, M. As cidadanias mutiladas. In: LERNER, J. (Ed). O Preconceito. São Paulo: Imprensa Oficial do Estado, 1996/1997.

SÃO LUIS DO PARAITINGA (Município). Formulário de Avaliação de Danos. 01 jan. 2010.

SIENA, M. A Atenção social nos desastres: uma análise sociológica das diversas concepções de atendimento aos grupos sociais afetados. 2012. Tese (Doutorado em Sociologia) - Universidade Federal de São Carlos, São Carlos, 2012.

SOROKIN, P. A. Man and Society in Calamity: the effects of war, revolution, famine and pestilence upon human mind, behavior, social organization and cultural life. New York: E. P. Dutton and Company Inc, 1942.

VALENCIO, N. Para além do 'Dia do Desastre'. 1. ed. (Coleção Ciências Sociais) Curitiba: Appris, 2012.

VALENCIO, N.; VALENCIO, A. 0 desastre como locus da barbárie: apontamentos sobre o caso brasileiro. In: (Orgs.).

Sociologia dos desastres: construção, interfaces e perspectivas no Brasil. v. II. São Carlos: RiMa, 2010, p. 31-52.

VALENCIO, N. F. L. S. Desastres: tecnicismo e sofrimento social. Ciência e Saúde Coletiva, v. 19, n. 9, p. 3631-3644, 2014.

VIANA, A. S. et al. Desastres ambientais e envelhecimento populacional. In: VALENCIO, N. (Org.) Sociologia dos desastres: construção, interfaces e perspectivas no Brasil. v. III. São Carlos: RiMa, 2013, p. 278-290. 


\section{RESUMO}

No Brasil, os desastres relacionados às chuvas são recorrentes e compõem, aproximadamente, um quarto do total anual dos desastres relacionados à água oficialmente registrados. Visando a compreender perturbações geradas por um desastre relacionado às chuvas nas rotinas da vida cotidiana dos moradores, no que diz respeito a alguns dos aspectos sociais mais relevantes para a vida privada e coletiva local, o presente trabalho analisa a memória comum de idosos em relação ao acontecimento que irrompeu no município de São Luiz do $\mathrm{Pa}$ raitinga/SP, em janeiro de 2010. Faz-se uso do termo "desastre vivenciado" para dar destaque à abordagem sociológica das narrativas daqueles que estão no centro desse tipo de crise e que são considerados como sendo os guardadores da memória social local. É um contraponto às narrativas oficiais. A sintese conceitual e documental no tema forneceu os elementos preliminares para a pesquisa de campo. Por meio desta última, foram obtidos os relatos orais de idosos que foram gravemente afetados no referido desastre. As conclusões indicam que o vivenciamento de um desastre por moradores idosos exige deles um intenso e doloroso trabalho de reelaboração do passado e de sua vida cotidiana presente. Tal reelaboração assenta tanto a narrativa deles em torno das limitações materiais nas circunstâncias do presente, quanto reporta as agruras que, na perspectiva dos entrevistados, o futuro próximo lhes reserva.

\section{PALAVRAS-CHAVE}

Desastres. Idosos. Memória social.

\section{ABSTRACT}

Disasters related to rainfall are recurrent in Brazil, and compose about a quarter of the annual amount of disaster decrees. With the purpose of understanding the disturbances created by a disaster related to rainfall in the quotidian life of citizens, referring to the relevant social aspects for the private and collective life of these citizens, the present work analyses the commons memories of the elderly about the disaster occurred in the municipality of São Luis do Paraitinga (Brazil) in January 2010. We employ the term living disaster to give emphasis to the sociological approach of the personal and collective narratives that people who are in the centre of this type of crisis, and too who are regarded by the community as the guardians of the local social memory. It is a counterpoint to the official narratives. The preliminary conceptual and documentary research in the theme has provided the elements for conducting the field research. In the latter, it were obtained the narratives from the elderly most severely affected in the referred disaster. The conclusions indicate that the experience of a disaster by old aged person citizens demands from them an intense and painful work of re-significance of the past, as well as of their present quotidian life. Such re-significance settles both the narrative of the individuals around the material limitations in the present, and the hardships that the future holds, according to the view expressed by the interviewees.

\section{KEYWORDS}

Disaster. Elderly. Social Memory. 